\title{
GEOLOGIA, PETROGRAFIA E GEOQUÍMICA DO GRANITO ANOROGÊNICO BANNACH, TERRENO GRANITO-GREENSTONE DE RIO MARIA, PARÁ
}

\author{
JOSÉ DE ARIMATÉIA COSTA DE ALMEIDA ${ }^{1,4}$, ROBERTO DALL'AGNOL $^{1,2}$ \& \\ DAVIS CARVALHO DE OLIVEIRA ${ }^{1,3}$
}

\begin{abstract}
Resumo O Granito Bannach é um batólito anorogênico intrusivo em unidades arqueanas do Terreno Granito-Greenstone de Rio Maria, sudeste do Cráton Amazônico. Ele é constituído por oito fácies petrográficas, todas monzograníticas: clinopiroxênio-biotita-anfibólio-monzogranito equigranular grosso, biotita-anfibólio-monzogranito equigranular grosso, anfibólio-biotitamonzogranito equigranular grosso, biotita-monzogranito porfirítico, leucomonzogranito equigranular grosso, leucomonzogranito equigranular médio precoce e tardio e leucomonzogranitos equigranular fino. A distribuição faciológica do corpo mostra que o maciço é zonado, com as fácies menos evoluídas ocupando as porções periféricas e as mais evoluídas as centrais. O Batólito Bannach é subalcalino, metaluminoso a peraluminoso, e possui altas razões $\mathrm{FeOt} /(\mathrm{FeOt}+\mathrm{MgO})(0,86$ a 0,97$)$ e $\mathrm{K}_{2} \mathrm{O} / \mathrm{Na}_{2} \mathrm{O}(1 \mathrm{a} 2)$. As diferentes fácies apresentam fracionamento fraco a moderado de ETR pesados e revelam anomalias negativas de európio as quais aumentam das fácies menos evoluídas para as mais evoluídas. Ele mostra afinidades geoquímicas com granitos intraplaca, granitos tipo-A do subtipo A2 e granitos ferrosos.

As relações de campo e os aspectos petrográfícos e geoquímicos indicam que as diversas fácies do Granito Bannach evoluíram por cristalização fracionada, comandada pelo fracionamento de titanomagnetita + ilmenita + zircão + apatita + hornblenda \pm clinopiroxênio e feldspatos, com um trend de diferenciação no sentido biotita-anfibólio-monzogranito equigranular grosso $\leftrightarrow$ anfibólio-biotita-monzogranito equigranular grosso $\leftrightarrow$ biotita-monzogranito porfirítico leucomonzogranito equigranular grosso $\leftrightarrow$ leucomonzogranito equigranular médio precoce $\leftrightarrow$ leucomonzogranitos equigranular fino. O leucomonzogranito equigranular médio tardio representaria uma intrusão separada, formada de um líquido muito evoluído e independente daquele formador das demais fácies. Os dados geoquímicos revelam que o líquido formador da fácies biotita-anfibólio-monzogranito equigranular grosso não poderia ter derivado do clinopiroxênio-biotita-anfibólio-monzogranito por processos de cristalização fracionada. O clinopiroxênio-biotita-anfibólio-monzogranito possui uma evolução magmática particular, com participação de processos cumuláticos. As características do Granito Bannach justificam enquadrá-lo na Suíte Jamon, uma vez que ele apresenta notáveis similaridades com os corpos Jamon, Musa e Redenção, que compõem a mesma.
\end{abstract}

Palavras-chaves: Cráton Amazônico, Anorogênico, Granitos tipo-A, Paleoproterozóico.

\begin{abstract}
GEOLOGY, PETROGRAPHY AND GEOCHEMISTRY OF THE ANOROGENIC BANNACH GRANITE, RIO MARIA GRANITE-GREENSTONE TERRANE, PARÁ. The Bannach Granite is intrusive in to Archean rocks of the Rio Maria Granite-Greenstone Terrane, located at the southeastern border of the Amazonian craton. Eigth varieties of monzogranites have been recognized in this Paleoproterozoic batholith: amphibole + biotite \pm clinopyroxene coarse-grained monzogranites: clinopyroxene-biotite-amphibole monzogranite, biotite-amphibole monzogranite, and amphibole-biotite monzogranite; Porphyritic biotite monzogranite; leucomonzogranites (coarse-grained, early and late medium-even-grained monzogranite and fine, even-grained monzogranite). The massif is zoned with the less evolved facies situated along the border and the more evolved facies in the center. The different facies are subalkaline, metaluminous to peraluminous, display $\mathrm{K}_{2} \mathrm{O} / \mathrm{Na}_{2} \mathrm{O}$ ratios between 1 and 2 and $\mathrm{FeOt} /(\mathrm{FeOt}+$ $\mathrm{MgO}$ ) between 0.86 and 0.97 . They show weak or moderate fractionation of heavy REE and negative europium anomalies that increase from the less evolved to the more evolved facies. The different facies display geochemical affinities with within-plate granites and A-type granites of the A2-subtype and are classified as ferroan granites.

The Bannach granite evolved through fractional crystallization of titanomagnetite + ilmenite + zircon + apatite + hornblende \pm clinopyroxene and feldspars minerals. The diferentiation trend was in the sense: $\leftrightarrow$ biotite-amphibole monzogranite $\leftrightarrow$ amphibole-biotite monzogranite $\leftrightarrow$ Worphyritic biotite monzogranite $\leftrightarrow$ leucomonzogranites. The late medium-even-grained leucomonzogranites facies is interpreted as a separate intrusion derived from strongly evolved liquids. The compositional gap between the clinopyroxene-biotite-amphibole monzogranite and the biotite-amphibole monzogranite facies suggests that the biotite-amphibole monzogranite liquid was not derived from the clinopyroxene-biotite-amphibole monzogranite by a simple fractional crystallization process. The clinopyroxene-biotite-amphibole monzogranite had a particular magmatic evolution, involving the participation of cumulatic processes. The Bannach granite displays a remarkable similarity with the Jamon, Musa and Redenção granites which constitute the Jamon Suite, justifying the attribution of the former to this suite.
\end{abstract}

Keywords: Amazonian Craton, Anorogenic, A-type granite, Paleoproterozoic.

INTRODUÇÃO Durante o Paleoproterozóico, o Cráton Amazônico foi palco de um extenso magmatismo granítico anorogênico (Dall'Agnol et al. 1994). Na região de Rio Maria este evento é marcado pela Suíte Jamon (Dall'Agnol et al. 2005) representada pelos Granitos Jamon (Dall'Agnol et al. 1999), Musa, Marajoara (Gastal 1987), Manda Saia (CPRM 2000, Leite 2001), Redenção (Montalvão et al. 1982, Vale \& Neves 1994,
Oliveira 2001) e Bannach (DOCEGEO 1988). Diferentemente dos outros corpos graníticos que compõem a Suíte Jamon, o Granito Bannach apresentava até o presente estudo, ausência de mapeamento geológico detalhado e escassez de informações petrográficas e geoquímicas. Portanto, o principal objetivo da pesquisa foi caracterizar o Granito Bannach no que diz respeito aos seus aspectos geológicos, petrográficos e geoquímicos e,

1 - Grupo de Pesquisa Petrologia de Granitóides (GPPG) - Centro de Geociências (CG) - Universidade Federal do Pará (UFPA). Caixa Postal 1611, Cep-66075-900, Belém, Pará. ari@ufpa.br

2 - Departamento de Petrologia e Geoquímica - CG - UFPA.robdal@ufpa.br

3 - Curso de Pós-Graduação em Geologia e Geoquímica (CPGG) - Campus Marabá - UFPA. davis@ufpa.br 


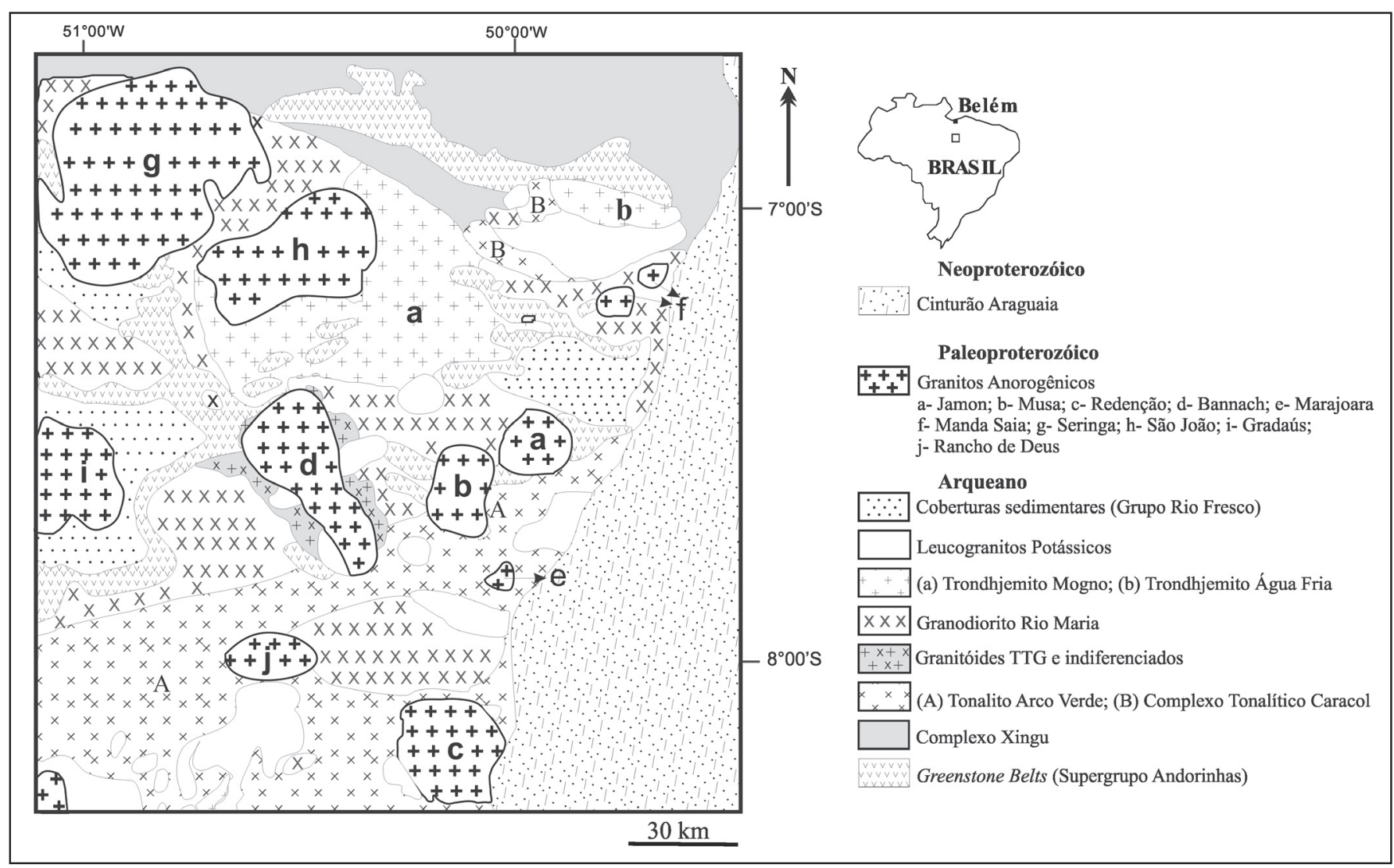

Figura 1 - Mapa Geológico do Terreno Granito-Greenstone de Rio Maria reproduzido a partir de Oliveira (2001) modificado; Fontes: Huhn et al. (1988), Souza (1994), CPRM (2000), Althoff et al. (2000), Leite (2001).

com isso, avaliar se o enquadramento desse corpo granítico na Suíte Jamon é justificado.

Os granitos tipo A oxidados têm obtido crescente destaque na literatura, tendo grande relevância no Proterozóico Médio dos Estados Unidos (Anderson \& Morrison 2005), assim como no Cráton Amazônico em particular no Terreno Granito-Greenstone de Rio Maria (Dall'Agnol et al. 1999, 2005). O estudo do Granito Bannach que se enquadra entre tais granitos, auxiliará na compreensão da evolução dos mesmos.

CONTEXTO GEOLÓGICO REGIONAL A região de Bannach está localizada na porção oeste do Terreno Granito-Greenstone de Rio Maria (TGGRM; Figura 1), borda sudeste do Cráton Amazônico, dentro da Província Amazônia Central (Tassinari \& Macambira 1999). O TGGRM é formado por greenstone belts e granitóides, ambos de idade arqueana. Os greenstone belts do Supergrupo Andorinhas (Souza 1994) é a unidade mais antiga da região. É possível distinguir três principais grupos de granitóides arqueanos (Dall'Agnol et al. 1997, Leite 2001): 1) Granitóides da Série Tonalítica-Trondhjemítica-Granodiorítica (TTG), sendo que os mais antigos são representados pelo Tonalito Arco Verde e Complexo Tonalítico Caracol e os mais novos pelo Trondhjemito Mogno e Trondhjemito Água Fria; 2) Granitóides do tipo sanukitóide é representado pelo Granodiorito Rio Maria e 3) Leucogranitos potássicos de afinidade cálcico-alcalina como é o caso dos granitos Xinguara, Mata Surrão, Guarantã e correlatos. As diversas unidades do TGGRM são cobertas por metassedimentos de idade arqueana do Grupo Rio Fresco e cortados por granitos anorogênicos paleoproterozóicos da Suíte Jamon.

GEOLOGIA DO BATÓLITO BANNACH. O Granito Bannach é um batólito (com aproximadamente $800 \mathrm{~km}^{2}$ ) alongado na direção NNW (Figura 2), intrusivo em unidades arqueanas, seccionando sua foliação regional E-W. Os contatos entre o corpo Bannach e as encaixantes são em geral bruscos e bem expostos, sendo comuns na zona de contato, a presença de enclaves angulosos de rochas encaixantes englobados pelo Granito Bannach. Este secciona granitóides thondhjemíticos e tonalíticos indiferenciados, Granodiorito Rio Maria, Greenstone-belts e Leucogranitos Potássico do tipo Xinguara e Mata Surrão. Diques de granito pórfiro e de rochas máficas de orientação E-W e ESE-WNW seccionam tanto o corpo Bannach como suas encaixantes.

As dificuldades de acesso à porção sul do corpo não permitiram uma amostragem detalhada, embora tenham possibilitado estender os domínios do Granito Bannach para esta área. Em razão disso, a distribuição de fácies só foi definida nas porções central e norte do corpo.

O maciço granítico Bannach é formado essencialmente por monzogranítos isotrópicos, tendo sido distinguidos três grandes conjuntos petrográficos: a) fácies de granulação grossa portadoras de anfibólio + biotita \pm clinopiroxênio, representadas por: Clinopiroxênio-biotita-anfibólio-monzogranito grosso (CBA$\mathrm{MzG})$, biotita-anfibólio-monzogranito grosso (BAMzG) e anfibólio-biotita-monzogranito grosso $(\mathrm{ABMzG})$; b) fácies portadora de biotita com textura porfirítica $(\mathrm{BMzP})$ e c) fácies leucograníticas, com termos com granulação grossa ( $\mathrm{LMzG})$, média [precoces (LMzMp) e tardio (LMzMt)] e fina (LMzF).

As rochas de granulação grossa (BAMzG, ABMzG e LMzG) são as de maior expressão areal do granito e independente das proporções das fases máficas, ocorrem de modo francamente dominante nas porções de baixo relevo do corpo com cotas que variam entre 450 e 600 metros.

O relevo acidentado do maciço é formado por dois padrões geomorfológicos: a) morros constituídos essencialmente por 


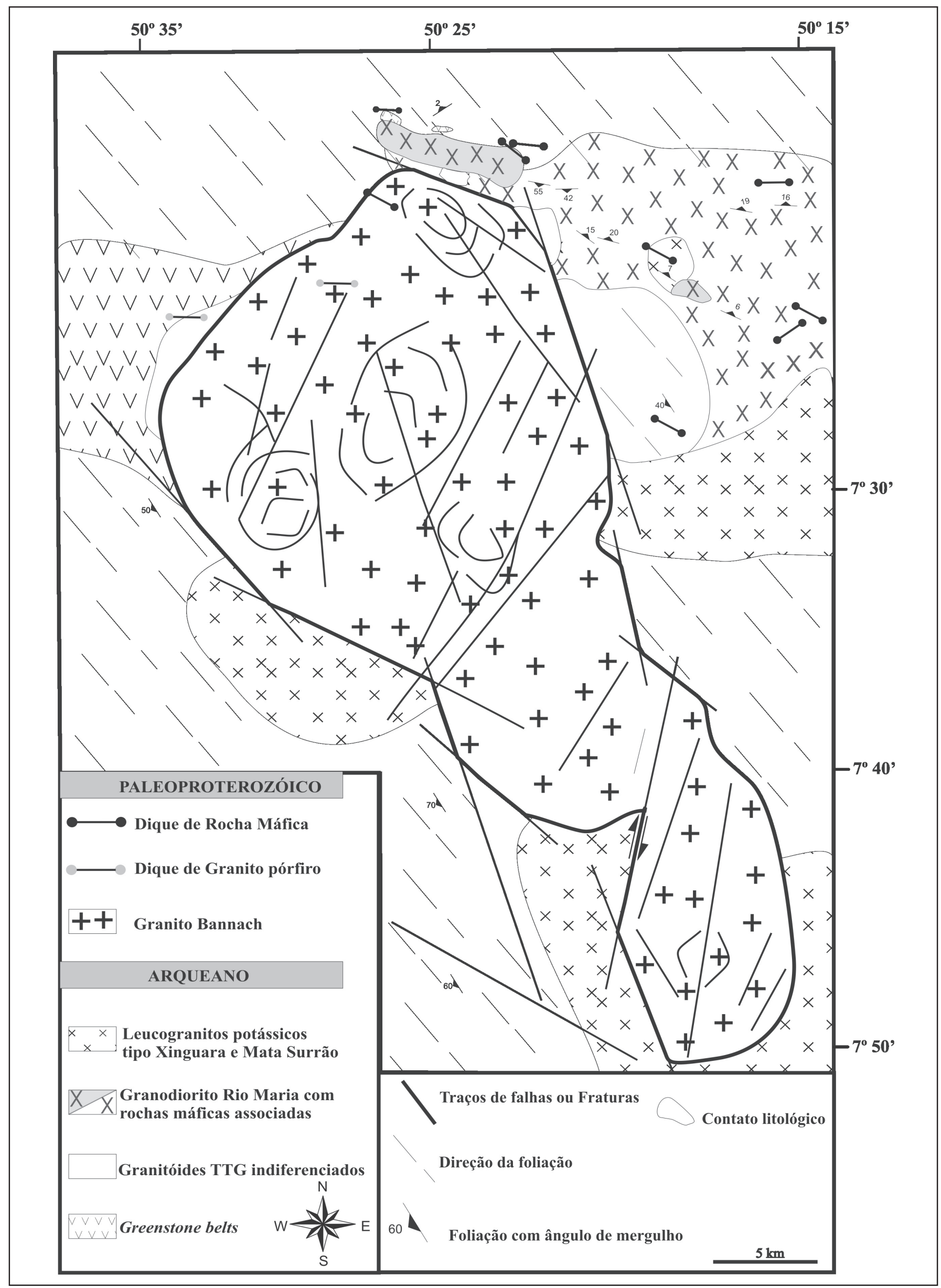

Figura 2 - Mapa Geológico da região de ocorrência do Granito Bannnach. 


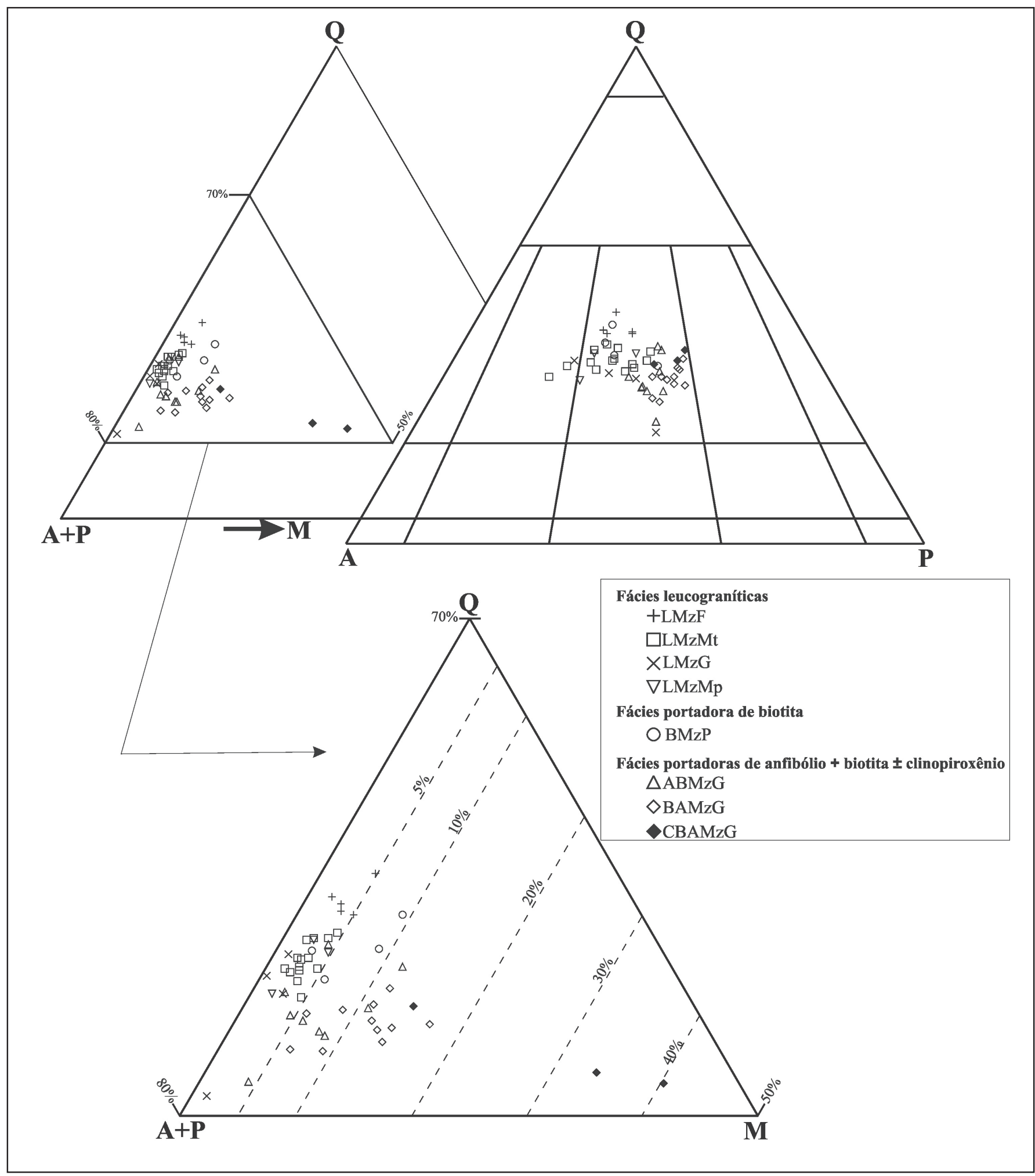

Figura 3 - Diagramas modais Q-A-P (Le Maître 2002)) e Q-(A+P)-M para as variedades do Granito Bannach. Abreviações: $C B A M z G$-clinopiroxênio-biotita-anfibólio-monzogranito equigranular grosso; BAMzG - biotita-anfibólio-monzogranito equigranular grosso; $A B M z G$ - anfibólio-biotita-monzogranito equigranular grosso; BMzP - biotita-monzogranito porfiritico; LMzG - leucomonzogranito equigranular grosso; LMzMp - leucomonzogranito equigranular médio precoce; LMzMt - leucomonzogranito equigranular médio tardio; LMzF - leucomonzogranito equigranular fino.

LMzMt, ocorrem no centro do corpo e mostram padrões concêntricos, formando anfiteatros com altitudes variando entre 600 até $650 \mathrm{~m}$; b) morros constituídos de $\mathrm{LMzF}$ e BMzP fortemente orientados na direção NE-SW com cotas que alcançam até 700 $\mathrm{m}$. Na parte norte do plutón, tais morros são interpretados como sendo relacionados a corpos tardios alinhados, os quais seccionam as demais variedades do maciço.

Os CBAMzG ocorrem em blocos restritos, exibindo geralmente contatos bruscos com os ABMzG ou LMzG, ou como autólitos arredondados no interior dos $\mathrm{ABMzG}$. Os BAMzG ocor- 
rem como enclaves nos $\mathrm{BMzP}$ e LMzF, geralmente com sinais de reabsorção. A fácies $\mathrm{ABMzG}$ é cortada por diques de $\mathrm{LMzF}$ e ocorre como enclaves com contornos difusos ou interdigitados englobados por essas rochas. Isso sugere a atuação localizada de processos de mingling envolvendo os líquidos formadores dessas duas fácies, o que implica baixo contraste térmico e de viscosidade entre ambas.

Observou-se, por vezes, uma aparente transição entre as fácies $\mathrm{BAMzG}, \mathrm{ABMzG}$ e $\mathrm{LMzG}$, passando das fácies mais enriquecidas em máficos para as mais leucocráticas. A interação entre estas fácies sugere baixo contraste de viscosidade entre elas, indicando que os líquidos formadores dos $\mathrm{BAMzG}$ e AB$\mathrm{MzG}$ não estavam inteiramente cristalizados quando os $\mathrm{LMzG}$ foram colocados em contatos com os mesmos.

As rochas da fácies $\mathrm{LMzG}$ encontram-se geralmente nas encostas das serras sustentadas por BMzP e mostram contatos gradacionais com os mesmos, marcados pelo acentuado desenvolvimento de textura rapakivi. A mesma feição ocorre em torno dos enclaves de $\mathrm{LMzF}$ nos $\mathrm{ABMzG}$. Ela pode ser explicada pela interação parcial (mingling) entre dois líquidos de composições distintas (Hibbard 1995). Os LMzF ora mantêm contatos transicionais com os BMzP, ora seccionam os mesmos. Eles cortam também os $\mathrm{LMzG}$ na forma de veios, mostrando geralmente nos seus domínios internos fenocristais esparsos de plagioclásio provenientes ao que tudo indica do $\mathrm{LMzG}$, revelando transferência relacionada com processos de mingling (Hibbard 1995).

A diferença entre os LMzMp e LMzMt é justificada pelas relações de campo e pelo contraste geoquímico entre ambos. Os primeiros ocorrem como enclaves no $\mathrm{ABMzG}$; já os LMzMt afloram nas estruturas circulares no interior do corpo, sendo tardios em relação ao $\mathrm{ABMzG}$ e geoquimicamente mais evoluídos.

\section{PETROGRAFIA}

Composições modal e classificação As composições modais de 53 amostras das diferentes fácies do Granito Bannach, foram plotadas nos diagramas Q-A-P e Q-A+P-M (Figura 3), e a tabela 1 mostra a composição média das diferentes fácies do corpo.

O maciço Bannach apresenta oito fácies petrográficas todas monzograníticas: Granito cumulático equigranular (CBAMzG), biotita-anfibólio-monzogranito equigranular grosso (BAMzG), anfibólio-biotita-monzogranito equigranular grosso (ABMzG), biotita-monzogranito porfirítico $(\mathrm{BMzP})$, leucomonzogranito equigranular grosso (LMzG), leucomonzogranito equigranular médio precoce (LMzMp) e tardio (LMzMt) e leucomonzogranitos equigranular fino (LMzF).

A paragênese essencial das diferentes fácies do Granito Bannach é representada por quartzo, microclina e plagioclásio. Os dados modais plotados no diagrama Q-A-P (Le Maitre 2002), demonstram que os conteúdos destes minerais variam significativamente, porém não deslocam-se do campo dos monzogranitos, a não ser em raras amostras da fácies LMzMt.

$\mathrm{O}$ diagrama $\mathrm{Q}-(\mathrm{A}+\mathrm{P})-\mathrm{M}$ permite separar domínios de rochas com maior conteúdo de máficos daquelas hololeucocráticas. Os CBAMzG possuem os maiores conteúdos médios de minerais máficos (M) (29,8\%), sendo seguidas pelas fácies BAMzG $(11,3 \%)$ e $\mathrm{ABMzG}(6,9 \%)$. A fácies BMzP possui valor médio de $\mathrm{M}$ de $6,7 \%$ e as fácies leucograníticas possuem valores de $\mathrm{M}$ $<4 \%$. Todas as fácies do Granito Bannach, com exceção dos CBAMzG e dos BAMzG, são classificáveis como hololeucocráticas, porém a designação de leucogranitos aplica-se apenas para as fácies com $\mathrm{M}<5 \%$ (Le Maitre 2002).

$\mathrm{O}$ anfibólio e a biotita são os principais ferromagnesianos, sendo que nas fácies mais enriquecidas em máficos (CBAMzG e BAMzG), o anfibólio está sempre presente em quantidades mais expressivas que os demais minerais máficos. À medida que diminui a quantidade total de ferromagnesianos das fácies, o anfibólio cede lugar gradativamente à biotita. À medida que as rochas se tornam mais holeucocráticas, o anfibólio se torna muito escasso ou mesmo ausente, as proporções de biotita diminuem e as de clorita tornam-se mais expressivas.

Os valores modais médios revelam que a razão plagioclásio/ microclinio $(\mathrm{Pl} / \mathrm{Mc})$ diminui no sentido $\mathrm{CBAMzG}(1,5) \rightarrow \mathrm{BA}-$ $\mathrm{MzG}(1,4) \rightarrow \mathrm{ABMzG}(1,2)$ e mantém-se praticamente constante em torno de 0,9 e 0,7 para as fácies BMzP, LMzMp, LMzMt, LMzG e LMzF, ao passo que o conteúdo de quartzo cresce dos CBAMzG (26\%), passando pelos BAMzG (29\%) e ABMzG $(30,4 \%)$ até os $\mathrm{LMzG}(31 \%)$, sendo que os maiores valores estão associados com as fácies leucograníticas 35,1 a 41,5\%. Portanto, em linhas gerais, as razões $\mathrm{Pl} / \mathrm{Mc}$ e os valores de $\mathrm{M}$ tendem a exibir valores decrescentes no sentido CBAMzG-BAMzG-ABMzG-BMzP-LMzF-LMzMp-LMzMt-LMzG, sendo que o contrário é observado para os conteúdos de quartzo.

Os minerais acessórios mais importantes, presentes em quantidades variadas nas diferentes fácies, são: zircão, titanita, apatita, allanita e opacos. Como minerais secundários encontram-se: clorita, sericita-muscovita, epídoto, fluorita e argilos-minerais.

O mapa geológico da porção norte (Figura 4) mostra a distribuição e as composições modais médias, em termos de quartzo, fedspato potássico, plagioclásio e máficos, das diferentes fácies do Granito Bannach. As fácies com maior conteúdo de minerais máficos (CBAMzG e BAMzG) tendem se concentrar nas borda do corpo. A fácies $\mathrm{ABMzG}$ é a que possui maior distribuição espacial, ocorrendo desde a porção central até zonas localizadas de borda. Os LMzMt possuem quatro domínios bem definidos nas porções centrais, já os LMzMp ocorrem de modo muito localizado nas porções centrais e sempre associados com enclaves nos ABMzG. Os BMzP e LMzF concentram-se no centro, no entanto eles ocorrem também ao longo de todo corpo associados com as demais fácies. As variações composicionais no interior do corpo sugerem a existência de um zoneamento aproximadamente concêntrico, com as fácies menos evoluídas tendendo a ocupar a periferia e as mais evoluídas as porções centrais do corpo.

\section{Aspectos texturais das principais variedades petrográficas.}

Fácies portadoras de anfibólio + biotita \pm clinopirox Ênio (CBA$M z G, B A M z G E A B M z G) \quad$ Os CBAMzG possuem maior conteúdo de máficos, apresentam uma textura equigranular grossa e é perceptível o arranjo dos minerais máficos formando pequenos agregados circundados por plagioclásio e presença marcante de clinopiroxênio modal. As fácies $\mathrm{BAMzG}$ e $\mathrm{ABMzG}$ diferem do $\mathrm{CBAMzG}$ por possuírem menores quantidades de máficos e plagioclásio e proporções superiores de feldspato alcalino. É comum o desenvolvimento de textura rapakivi nesse conjunto de rochas.

Ao microscópio essas rochas mostram textura granular hipidiomórfica grossa, localmente tendendo a porfirítica, devido ao maior desenvolvimento dos fedspatos. São comuns, principalmente nos CBAMzG e BAMzG agregados de minerais máficos (0,2 - $4 \mathrm{~mm})$ associados a concentrações de cristais geralmente alterados de plagioclásio Nessas fácies, os agregados máficos são mais comuns e o anfibólio é dominante, podendo envolver relíquias de clinopiroxênio. Nos $\mathrm{ABMzG}$, a biotita passa a ser o máfico predominante, em função da intensa desestabilização do anfibólio, o clinopiroxênio é muito raro e os agregados máficos são mais dispersos e não mostram uma associação tão constante com as concentrações de cristais de plagioclásio.

É muito freqüente em todas às fácies deste grupo, o plagioclásio constituir agregados de cristais, cujas composições são geralmente de andesina sódica $\left(\mathrm{An}_{30}\right)$ a oligoclásio cálcico $\left(\mathrm{An}_{24}\right)$, nas porções centrais dos cristais, variando na borda de oligoclásio sódico $\left(\mathrm{An}_{15}\right)$ até albita pura $\left(\mathrm{An}_{0}\right)$.

Fácies porfiritica portadora de biotita $(B M z P)$. Os granitos 
Tabela 1 - Composições modais médias das diferentes fácies do Granito Bannach. Abreviações: C-clinopiroxênio; B - biotita; $A$ - anfibólio; $M z$-monzogranito; $G$-grosso; $M$-médio; $F$-fino; $P$-porfirítico; $L$-leuco; $p$-precoce; $t$-tardio; \{\} número de amostras analisadas.

\begin{tabular}{|c|c|c|c|c|c|c|c|c|}
\hline \multirow{3}{*}{ Mineral(\%) } & \multicolumn{3}{|c|}{ Fácies portadoras de anfibólio + biotita \pm clinopiroxênio } & \multirow{2}{*}{$\frac{\text { Fácies portadora de biotita }}{\mathrm{BMzP}}$} & \multicolumn{4}{|c|}{ Fácies Leucograníticas } \\
\hline & CBAMzG & BAMzG & $\mathrm{ABMzG}$ & & LMzMp & LMzG & LMzMt & $\mathrm{LMzF}$ \\
\hline & $\{3\}$ & $\{11\}$ & $\{9\}$ & $\{4\}$ & $\{3\}$ & $\{4\}$ & $\{14\}$ & $\{5\}$ \\
\hline Quartzo & 26,0 & 29,0 & 30,4 & 36,6 & 35,2 & 31,0 & 35,1 & 41,5 \\
\hline K-feldspato & 17,8 & 24,2 & 28,7 & 30,1 & 35,6 & 36,3 & 34,6 & 29,9 \\
\hline Plagioclásio & 26,4 & 34,5 & 33,6 & 26,1 & 25,2 & 30,8 & 25,7 & 24,3 \\
\hline Biotita & 7,5 & 2,7 & 3,8 & 2,9 & 1,1 & 0,3 & 1,8 & 1,2 \\
\hline Anfibólio & 16,4 & 5,3 & 1,4 & - & 1,0 & 0,2 & - & - \\
\hline Clinopiroxênio & 0,9 & 0,4 & 0,1 & - & 0,2 & - & - & - \\
\hline Opacos & 3,8 & 1,9 & 0,7 & 1,4 & 0,4 & 0,2 & 0,1 & $<0,1$ \\
\hline Titanita & 0,4 & 0,1 & 0,2 & 0,6 & 0,1 & - & - & - \\
\hline Allanita & 0,2 & 0,2 & 0,3 & 0,2 & - & - & - & - \\
\hline Clorita & 0,1 & 0,3 & 0,3 & 1,5 & 0,6 & 0,7 & 1,1 & 2,5 \\
\hline Muscovita & - & - & 0,1 & - & 0,1 & - & 0,4 & 0,1 \\
\hline Fluorita & - & 0,2 & - & 0,1 & - & - & 0,1 & - \\
\hline Albita intergran. & - & 1,0 & 0,4 & 0,5 & 0,4 & 0,5 & 1,0 & 0,5 \\
\hline Acessórios $(\mathrm{Ap}+\mathrm{Zr})$ & 0,5 & 0,1 & 0,1 & $<0,1$ & 0,1 & - & - & $<0,1$ \\
\hline Félsicos & 70,2 & 88,7 & 93,1 & 93,3 & 96,4 & 98,5 & 96,4 & 96,3 \\
\hline Máficos & 29,8 & 11,3 & 6,9 & 6,7 & 3,6 & 1,5 & 3,6 & 3,7 \\
\hline$A+P$ & 44,2 & 58,7 & 62,3 & 56,1 & 60,8 & 67,0 & 60,3 & 54,3 \\
\hline $\mathrm{Q}+\mathrm{A}$ & 43,8 & 53,2 & 59,1 & 66,7 & 70,8 & 67,3 & 69,6 & 71,4 \\
\hline Biot + Clorita & 7,6 & 3,0 & 4,0 & 4,4 & 1,7 & 1,3 & 2,9 & 3,7 \\
\hline Anf/Biot & 2,2 & 2,0 & 0,4 & 0,0 & 0,9 & 0,6 & 0,0 & 0,0 \\
\hline \multicolumn{9}{|l|}{ À̀ $100 \%$} \\
\hline Quartzo & 37,1 & 33,1 & 32,8 & 39,5 & 36,7 & 31,6 & 36,8 & 43,3 \\
\hline K-feldspato & 25,0 & 27,6 & 30,9 & 32,4 & 37,2 & 37,0 & 36,2 & 31,3 \\
\hline Plagioclásio & 37,8 & 39,3 & 36,2 & 28,1 & 26,1 & 31,4 & 27,0 & 25,4 \\
\hline $\mathrm{Pl} / \mathrm{Fk}$ & 1,5 & 1,4 & 1,2 & 0,9 & 0,7 & 0,8 & 0,7 & 0,8 \\
\hline
\end{tabular}

porfiríticos possuem coloração rosada com tons avermelhados e são formados por fenocristais automorfos a subautomorfos de quartzo, plagioclásio e feldspato alcalino com dimensões geralmente entre 5 e $20 \mathrm{~mm}$ imersos numa matriz com cristais de tamanhos variáveis entre 0,2 e $2 \mathrm{~mm}$. Os fenocristais de quartzo geralmente apresentam baías de corrosão. Essa fácies também apresenta agregados de máficos e plagioclásio e que são, de modo geral, similares aos observados nos $\mathrm{ABMzG}$, porém menos freqüentes e mostra uma cloritização mais intensa. Os intercrescimentos granofíricos são comuns na matriz destas rochas. Muitas vezes cristais de quartzo dispõem-se subparalelamente aos contornos dos fenocristais de feldspato alcalino, marcando o crescimento dos mesmos. Nessas rochas, a matriz constitui cerca de 50 a $80 \%$ da rocha e é formada por cristais subautomorfos a xenomórficos de quartzo, plagioclásio, microclina e proporções variáveis de máficos. A composição dos plagioclásios da matriz é semelhante às bordas dos cristais das fácies portadoras de anfibólio + biotita \pm clinopiroxênio (oligoclásio sódico $\left(\mathrm{An}_{16}\right)$ até albita pura $\left.\left(\mathrm{An}_{5}\right)\right)$.

Fácies leucograniticas ( $L M z G, L M z M p, L M z M t E L M z F)$. A fácies $\mathrm{LMzG}$ é caracterizada por sua coloração rosada com tons avermelhados devida à maior proporção de feldspato alcalino em relação às fácies precedentes. A biotita e o anfibólio ocorrem como minerais reliquiares com pequenas dimensões e dispersos entre os minerais essenciais. A clorita torna-se relativamente mais abundante nesta fácies, ocorrendo como grãos dispersos ou associados com relíquias de biotita. Esta fácies apresenta textura granular hipidiomórfica e possui notável semelhança em termos do aspecto de quartzo e feldspatos as fácies BAMzG e ABMzG. No entanto, difere composicionalmente das mesmas no conteúdo de máficos. Os intercrescimentos granofíricos são muito freqüentes.

Os aspectos texturais das fácies LMzMp e LMzMt são similares, porém os LMzMp diferenciam-se dos LMzMt por apresentar anfibólio modal e restos de clinopiroxênio. Essas rochas exibem uma textura equigranular média com conteúdo muito reduzido de minerais ferromagnesianos dando caráter hololeucocrático para essas rochas.

As rochas da fácies LMzMt possuem coloração que varia de rosa a avermelhada e mostram ligeiros contrastes texturais, possibilitando separar dois tipos. O predominante possui textura equigranular média com pontuações escuras esparsas e se localiza nas bordas dessas estruturas, enquanto que o segundo ocupa o centro das mesmas, exibe textura equigranular fina e é ligeiramente mais rico em feldspato alcalino do que tipo o anterior. $\mathrm{O}$ segundo tipo é muito semelhante ao LMzF, embora possua menor quantidade de máficos e granulação um pouco mais grossa.

Ao microscópio, os LMzMt exibem textura equigranular hipidiomórfica, sendo o seu principal constituinte máfico a biotita, muitas vezes alterada para clorita. O plagioclásio acha-se pouco alterado e suas composições são mais sódicas em relação às das demais fácies. Os agregados de plagioclásio mais cálcico e de máficos estão ausentes e fases como muscovita e albita intergra- 


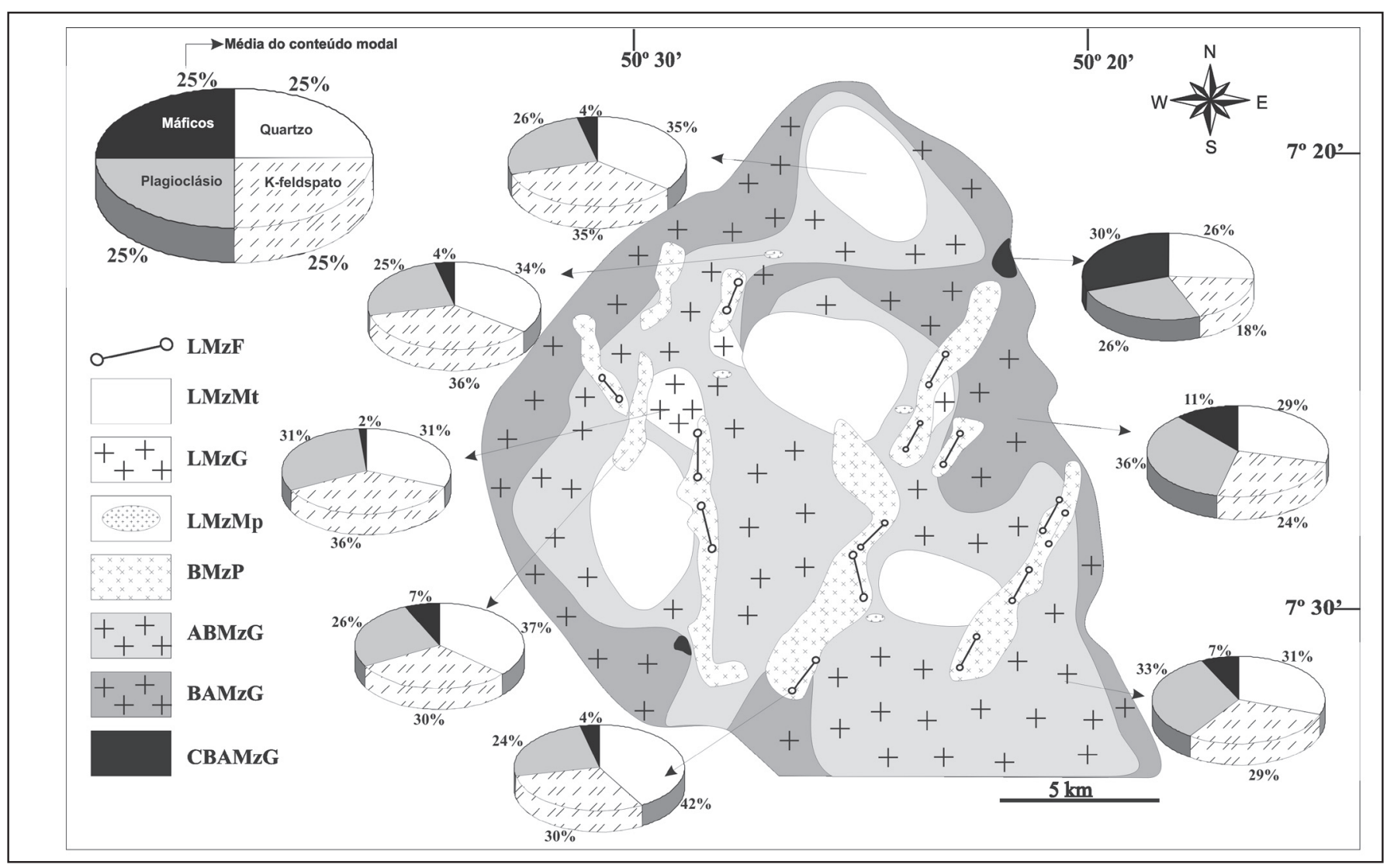

Figura 4 - Mapa geológico da porção norte do Granito Bannach, mostrando a distribuição das diferentes fácies e as suas composições modais médias. Abreviações: $C B A M z G$ - clinopiroxênio-biotita-anfibólio-monzogranito equigranular grosso; BAMzG biotita-anfibólio-monzogranito equigranular grosso; $A B M z G$ - anfibólio-ibiotita-monzogranito equigranular grosso; $B M z P$ - biotita-monzogranito porfirítico; LMzG - leucomonzogranito equigranular grosso; LMzMp - leucomonzogranito equigranular médio precoce; LMzMt - leucomonzogranito equigranular médio tardio; LMzF-leucomonzogranito equigranular fino.

nular são freqüentes nessas rochas.

Os leucomonzogranitos de granulação fina (LMzF) apresentam coloração avermelhada, com pequenas pontuações escuras e textura equigranular fina. Alguns tipos exibem coloração rosada, menor quantidade de máficos e textura muito fina; outros mostram caráter porfirítico, com fenocristais de quartzo, plagioclásio e feldspato alcalino, e razões fenocristais/matriz muito baixas $(<0,20)$. Estas rochas se assemelham muito com a matriz das rochas porfiríticas (BMzP). Microscopicamente possuem textura equigranular hipidiomórfica a xenomórfica e máficos representados por clorita e, subordinadamente, biotita. Em algumas amostras observa-se a maior presença de feldspato potássico, quartzo e plagioclásio, dando um aspecto porfirítico as mesmas, sendo comum o desenvolvimento de intercrescimentos granofíricos entre fenocristais de fedspato alcalino e quartzo.

\section{GEOQUÍMICA}

Elementos maiores A composição química média das diversas fácies do Granito Bannach (Tabela 2), mostra que o conteúdo de $\mathrm{SiO}_{2}$ das mesmas varia entre 58,1 e $76,3 \%$. Os teores de $\mathrm{SiO}_{2}$ permitem individualizar três grupos: (1) Rochas relativamente pobres em sílica $(58,1 \%)$ representadas pelos CBA$\mathrm{MzG}$; (2) Rochas com valores intermediários de $\mathrm{SiO}_{2}$, variando de 69,7 a 73,7\% com média de 71,5\% englobando as fácies BAMzG e ABMzG; (3) Rochas relativamente ricas em sílica, com teores médios acima de 75,5\% formadas pelo BMzP e por leucogranitos (LMzG, LMzMp, LMzMt e LMzF).

Nota-se uma diferença composicional marcante entre as rochas do grupo 2 e aquela do grupo 1 (CBAMzG). Este últi- mo, apresenta teor relativamente elevado de $\mathrm{TiO}_{2}, \mathrm{MgO}, \mathrm{Fe}_{2} \mathrm{O}_{3}$, $\mathrm{MnO}, \mathrm{CaO}$ e $\mathrm{P}_{2} \mathrm{O}_{5}$, e baixo de $\mathrm{SiO}_{2}, \mathrm{Al}_{2} \mathrm{O}_{3}, \mathrm{Na}_{2} \mathrm{O}, \mathrm{K}_{2} \mathrm{O}$, distinguindo-se das demais fácies do corpo. Isso, juntamente com os elevados conteúdos de máficos que os $\mathrm{CBAMzG}$ apresentam em relação às demais fácies portadoras de anfibólio + biotita \pm clinopiroxênio, não favorece a idéia de sua origem estar relacionada à cristalização fracionada. $\mathrm{O}$ fato dessas rochas ocorrerem geralmente nas borda do corpo Bannach e sempre associadas com os BAMzG também sugere a atuação de processos cumuláticos na sua gênese. Tal processo resultou provavelmente da segregação por decantação de fases precoces (anfibólio, clinopiroxênio e minerais acessórios) em um líquido similar ao que deu origem aos $\mathrm{BAMzG}$, ou seja, $\mathrm{CBAMzG}=\mathrm{BAMzG}+$ fases máficas cumuláticas. Contrastes locais de viscosidade e diferenças de densidade entre fases precoces e líquido residual do magma podem promover a separação gravimétrica de fases precoces (Wernick 2004).

Com o aumento de $\mathrm{SiO}_{2}$, os teores de $\mathrm{TiO}_{2}, \mathrm{MgO}, \mathrm{Fe}_{2} \mathrm{O}_{3}$, $\mathrm{MnO}, \mathrm{CaO}$ e $\mathrm{P}_{2} \mathrm{O}_{3}$ tendem a diminuir, e os conteúdos de $\mathrm{K}_{2} \mathrm{O}$ a aumentar, no sentido do grupo 1 ao 3 . Os valores de $\mathrm{Al}_{2} \mathrm{O}_{3} \mathrm{e}$ $\mathrm{Na}_{2} \mathrm{O}$ das diversas fácies formam um trend subhorizontal com aumento de $\mathrm{SiO}$

As razões $\mathrm{K}_{2} \mathrm{O} / \mathrm{Na}_{2} \mathrm{O}$ estão entre 1 e 2 (Tabela 2), caracterizando as diversas fácies como relativamente enriquecidas em $\mathrm{K}_{2} \mathrm{O}$ (Figura 5a). Observa-se a diminuição da razão $\mathrm{K}_{2} \mathrm{O} / \mathrm{Na}_{2} \mathrm{O}$ das fácies portadoras de anfibólio+biotita \pm clinopiroxênio para os leucogranitos.

Nos diagramas de Harker nota-se que o sentido da evolução do Granito Bannach segue aquele sugerido pela petrogra- 
Tabela 2 - Composições químicas médias das diversas fácies do Granito Bannach. Abreviações: C-clinopiroxênio; B - biotita; $A$ - anfibólio; $M z$-monzogranito; $G$-grosso; $M$-médio; $F$-fino; $P$-porfirítico; $L$-leuco; $p$-precoce; $t$-tardio; \{\} número de amostras analisadas.

\begin{tabular}{|c|c|c|c|c|c|c|c|c|}
\hline \multirow[t]{2}{*}{ Elementos } & \multicolumn{3}{|c|}{ Fácies portadoras de anfibólio + biotita \pm clinopiroxênio } & \multirow{2}{*}{\begin{tabular}{|c|} 
Fácies portadora de biotita \\
$\mathrm{BMzP}$
\end{tabular}} & \multirow[b]{2}{*}{ LMzMp } & \multicolumn{2}{|c|}{ Fácies Leucograníticas } & \multirow[b]{2}{*}{ LMzF } \\
\hline & CBAMzG & BAMzG & ABMzG & & & LMzG & LMzMt & \\
\hline Fácies & $\{1\}$ & $\{4\}$ & $\{5\}$ & $\{2\}$ & $\{2\}$ & $\{2\}$ & $\{5\}$ & $\{3\}$ \\
\hline $\mathrm{SiO}_{2}(\%)$ & 58,12 & 70,07 & 72,67 & 75,30 & 74,56 & 75,95 & 75,99 & 76,30 \\
\hline $\mathrm{TiO}_{2}$ & 2,41 & 0,67 & 0,35 & 0,28 & 0,10 & 0,17 & 0,11 & 0,14 \\
\hline $\mathrm{Al}_{2} \mathrm{O}_{3}$ & 9,17 & 12,82 & 12,86 & 11,65 & 12,94 & 11,74 & 12,05 & 11,67 \\
\hline $\mathrm{Fe}_{2} \mathrm{O}_{3}$ & 6,87 & 2,73 & 1,90 & 1,85 & 0,99 & 1,41 & 1,18 & 1,10 \\
\hline $\mathrm{FeO}$ & 8,86 & 1,70 & 0,66 & 0,37 & 0,13 & 0,10 & 0,13 & 0,17 \\
\hline $\mathrm{MnO}$ & 0,29 & 0,08 & 0,04 & 0,03 & 0,02 & 0,03 & 0,03 & 0,02 \\
\hline $\mathrm{MgO}$ & 2,48 & 0,56 & 0,27 & 0,21 & 0,13 & 0,10 & 0,05 & 0,06 \\
\hline $\mathrm{CaO}$ & 3,31 & 2,16 & 1,37 & 0,86 & 0,92 & 0,73 & 0,52 & 0,52 \\
\hline $\mathrm{Na}_{2} \mathrm{O}$ & 1,92 & 3,38 & 3,26 & 2,87 & 3,03 & 2,93 & 3,17 & 2,92 \\
\hline $\mathrm{K}_{2} \mathrm{O}$ & 3,10 & 3,84 & 4,86 & 4,58 & 5,06 & 5,21 & 4,83 & 5,12 \\
\hline $\mathrm{P}_{2} \mathrm{O}_{5}$ & 0,79 & 0,19 & 0,09 & 0,05 & 0,03 & 0,04 & 0,01 & 0,02 \\
\hline Total & 97,32 & 98,17 & 98,34 & 98,02 & 97,88 & 98,39 & 98,08 & 98,04 \\
\hline $\mathrm{Ba}(\mathrm{ppm})$ & 428 & 1408 & 906 & 641 & 1509 & 4447 & 116 & 249 \\
\hline $\mathrm{Rb}$ & 202 & 153 & 197 & 184 & 157 & 184 & 367 & 238 \\
\hline $\mathrm{Sr}$ & 107 & 228 & 143 & 117 & 173 & 57 & 25 & 54 \\
\hline $\mathrm{Zr}$ & 1684 & 397 & 293 & 276 & 128 & 145 & 166 & 113 \\
\hline $\mathrm{Nb}$ & 65 & 21 & 20 & 10 & 9 & 15 & 21 & 16 \\
\hline $\mathrm{Y}$ & 234 & 58 & 53 & 28 & 93 & 31 & 70 & 56 \\
\hline Ga & 27 & 21 & 21 & 19 & 16 & 18 & 21 & 20 \\
\hline $\mathrm{Sc}$ & 33 & 9 & 6 & 3 & 2 & 3 & 2 & 3 \\
\hline Th & 16 & 16 & 30 & 41 & 7 & 16 & 53 & 31 \\
\hline U & 7 & 4 & 5 & 4 & 2 & 3 & 10 & 4 \\
\hline V & 129 & 24 & 10 & 6 & 11 & $<5$ & $<5$ & $<5$ \\
\hline $\mathrm{La}$ & 158 & 77 & 90 & 197 & 94 & 50 & 89 & 114 \\
\hline $\mathrm{Ce}$ & 379 & 165 & 231 & 410 & 210 & 97 & 179 & 217 \\
\hline Pr & 51 & 18 & 23 & 36 & 23 & 10 & 18 & 23 \\
\hline $\mathrm{Nd}$ & 207 & 65 & 75 & 104 & 88 & 32 & 58 & 72 \\
\hline Sm & 44 & 12 & 13 & 12 & 16 & 5 & 10 & 11 \\
\hline Eu & 2 & 2 & 2 & 1 & 3 & 1 & 0 & 1 \\
\hline $\mathrm{Gd}$ & 39 & 10 & 10 & 7 & 15 & 5 & 8 & 9 \\
\hline $\mathrm{Tb}$ & 6 & 2 & 2 & 1 & 2 & 1 & 2 & 1 \\
\hline Dy & 37 & 9 & 9 & 5 & 13 & 5 & 9 & 9 \\
\hline Ho & 8 & 2 & 2 & 1 & 3 & 1 & 2 & 2 \\
\hline Er & 22 & 6 & 5 & 3 & 8 & 3 & 7 & 5 \\
\hline $\mathrm{Tm}$ & 3 & 1 & 1 & 0 & 1 & 0 & 1 & 1 \\
\hline $\mathrm{Yb}$ & 18 & 5 & 5 & 3 & 7 & 3 & 7 & 5 \\
\hline Lu & 3 & 1 & 1 & 0 & 1 & 0 & 1 & 1 \\
\hline Total & 976 & 373 & 415 & 779 & 485 & 213 & 391 & 470 \\
\hline $\mathrm{K}_{2} \mathrm{O} / \mathrm{Na}_{2} \mathrm{O}$ & 1,61 & 1,13 & 1,49 & 1,77 & 1,85 & 1,78 & 1,53 & 1,76 \\
\hline $\mathrm{FeOt} /(\mathrm{MgO}+\mathrm{FeOt})$ & 0,86 & 0,88 & 0,90 & 0,90 & 0,89 & 0,93 & 0,96 & 0,95 \\
\hline $\mathrm{A} / \mathrm{CNK}$ & 0,73 & 0,94 & 0,98 & 1,03 & 1,01 & 1,00 & 1,06 & 1,03 \\
\hline $\mathrm{Rb} / \mathrm{Sr}$ & 1,89 & 0,68 & 1,4 & 1,57 & 0,91 & 3,35 & 15,92 & 4,74 \\
\hline $\mathrm{Sr} / \mathrm{Ba}$ & 0,25 & 0,16 & 0,15 & 0,18 & 0,11 & 0,15 & 0,23 & 0,27 \\
\hline $\mathrm{Ba} / \mathrm{Rb}$ & 2,11 & 9,34 & 5,4 & 3,49 & 9,59 & 2,42 & 0,33 & 1,09 \\
\hline$(\mathrm{La} / \mathrm{Yb}) \mathrm{n}$ & 6,56 & 11,43 & 13,78 & 55,85 & 9,46 & 11,31 & 8,96 & 17,50 \\
\hline$(\mathrm{Gd} / \mathrm{Yb}) \mathrm{n}$ & 1,82 & 1,73 & 1,61 & 2,19 & 1,71 & 1,26 & 0,94 & 1,51 \\
\hline $\mathrm{Eu} / \mathrm{Eu} *$ & 0,18 & 0,70 & 0,44 & 0,44 & 0,65 & 0,53 & 0,16 & 0,31 \\
\hline
\end{tabular}

fia: CBAMzG (grupo1) BAMzG-ABMzG (grupo 2) BMzPLMzMp-LMzG-LMzMt-LMzF (Grupo 3). Entretanto, fica clara a descontinuidade composicional marcante entre os CBAMzG e as demais fácies petrográficas do corpo.

$\mathrm{O}$ diagrama $\mathrm{FeOt} /(\mathrm{FeOt}+\mathrm{MgO})$ versus $\mathrm{SiO}_{2}$ (Figura $5 \mathrm{~b}$ ) mostra que o Granito Bannach possui altas razões (sempre $>0,8$ ), as quais tendem a aumentar nas variedades mais ricas em sílica, refletindo o decréscimo mais acentuado de $\mathrm{MgO}$ do que de $\mathrm{FeOt}$ nestas rochas em relação às menos evoluídas (Tabela 2).

$\mathrm{O}$ caráter metaluminoso a peraluminoso do Granito Bannach, é evidenciado através do diagrama $\mathrm{Fe}+\mathrm{Mg}+\mathrm{Ti}$ versus $\mathrm{Al}-$ $(\mathrm{K}+\mathrm{Na}+2 \mathrm{Ca})$ (Figura 5c) de Debon et al. (1988). Ele mostra, que: com a diminuição de constituintes máficos as rochas passam de metaluminosas a peraluminosas; as amostras das fácies $\mathrm{CBAMzG}, \mathrm{BAMzG}$ e $\mathrm{ABMzG}$ incidem no campo das rochas com anfibólio e biotita (Campo IV); e as fácies LMzG, LMzMt, $\mathrm{LMzF}$ e algumas amostras da fácies $\mathrm{BMzP}$ seriam classificadas geoquimicamente como leucogranitos.

No diagrama $\mathrm{Si} / 3-(\mathrm{K}+\mathrm{Na}+2 \mathrm{Ca} / 3)$ versus $\mathrm{K}-(\mathrm{Na}+\mathrm{Ca})$ (Figura 5d) de Debon et al. (1988), verifica-se que as diversas fácies do Granito Bannach seguem um trend subalcalino potássico, com as amostras menos evoluídas (CBAMzG, BAMzG e ABMzG) localizando-se no campo onde há ligeira predominância de plagioclásio sobre o feldspato potássico $(\mathrm{P}<0)$, sendo o contrário 


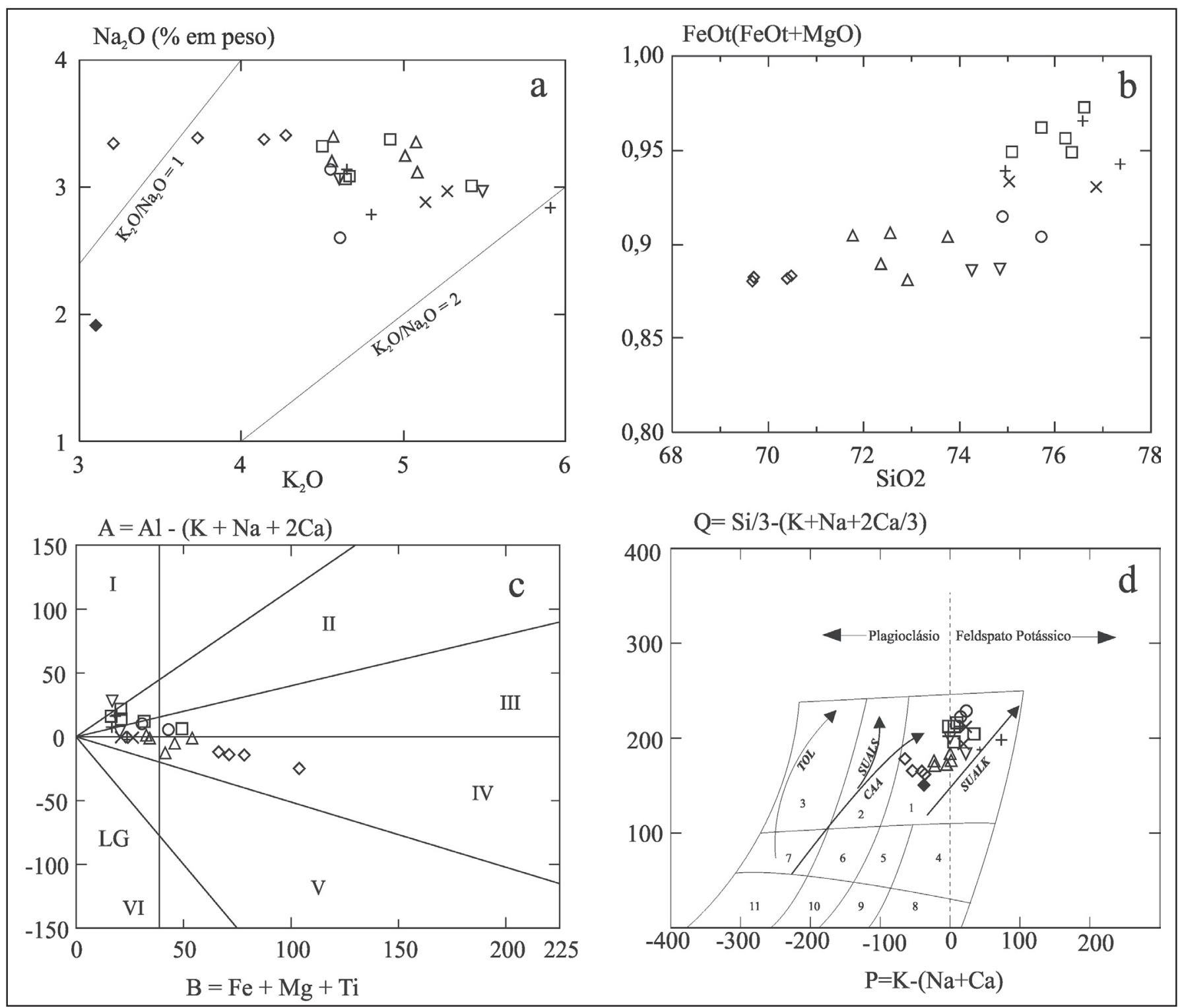

Figura 5 - Diagramas geoquímicos para as diversas fácies do Granito Bannach. a) diagrama $\mathrm{Na}_{2} \mathrm{O} \mathrm{X} \mathrm{K}_{2} \mathrm{O}$; b) diagrama FeOt/ $(\mathrm{FeOt}+\mathrm{MgO}) \mathrm{XSiO}_{2}$; c) diagrama A x B (Debon et al. 1988); Campos I-muscovita>biotita, II - biotita>muscovita, III - rochas apenas com biotita, IV-rochas com biotita, anfibólio \pm piroxênio, $V$-rochas com clinopiroxênio, VI-rochas ígneas excepcionais e LG - leucogranitóides; d) diagrama $Q \times P$ (Debon et al. 1988), mostrando a afinidade com as séries subalcalinas potássicas do Granito Bannach.Campos: 1 - Granito, 2- Granodiorito, 3 - Tonalito, 4 - Quartzo-Sienito, 5 - Quartzo-Monzonito, 6 - Quartzo-Monzodiorito, 7 - Quartzo-Diorito, 8 - Sienito, 9 - Monzonito, 10 - Monzogabro, 11 - Gabro; Abreviações: TOL=Toleitica, $C A A=$ Cálcico-Alcalina, SUBALS= Subalcalina Sódica, SUBALK= Subalcalina Potássica. Simbologia das fácies e suas abreviações conforme figura 3.

observado nos leucogranitos.

\section{ELEMENTOS-TRAÇO}

Comportamento do Rb, Sr e Ba. A maioria do Rb na crosta está contido em feldspato potássico e biotita (Wedepohl 1970), sendo que o conteúdo desse elemento aumenta, de acordo com a diferenciação magmática.

Os teores de $\mathrm{Rb}$ tendem a crescer ao longo da evolução das fácies do Granito Bannach, mostrando correlação positiva com $\mathrm{SiO}_{2}$ e um trend fortemente inclinado nos monzogranitos menos evoluídos (BAMzG-ABMzG) e subverticalizado no caso das rochas mais evoluídas.

Os conteúdos de $\mathrm{Sr}$ e Ba são muito baixos nos CBAMzG, alcançam valores máximos nos $\mathrm{BAMzG}$ e diminuem de modo marcante destes últimos para as demais fácies, no sentido BAMzG-
ABMzG-LMzMp-BMzP-LMzG-LMzMt-LMzF, apresentando, portanto, esses elementos um comportamento inverso ao do $\mathrm{Rb}$.

Segundo Wedepohl (1974), em líquidos silicáticos o Sr se concentra fundamentalmente em plagioclásios de composições intermediárias (andesina a oligoclásio cálcico) e subordinadamente no feldspato potássico. A separação do plagioclásio deve ter conduzido o empobrecimento de $\mathrm{Sr}$ no líquido e a cristalização não muito tardia do feldspato potássico deve ter contribuído para acentuar essa tendência.

Wedepohl (1972) mostra que o Ba é admitido mais facilmente no feldspato potássico e nas micas, mas teores significativos podem ocorrer em plagioclásios intermediários. No Granito Bannach a diminuição dos teores de Ba deve estar ligada ao fracionamento de microclina, biotita e, provavelmente, nos BAMzG e ABMzG de andesina-oligoclásio cálcico, minerais que consumiram em 

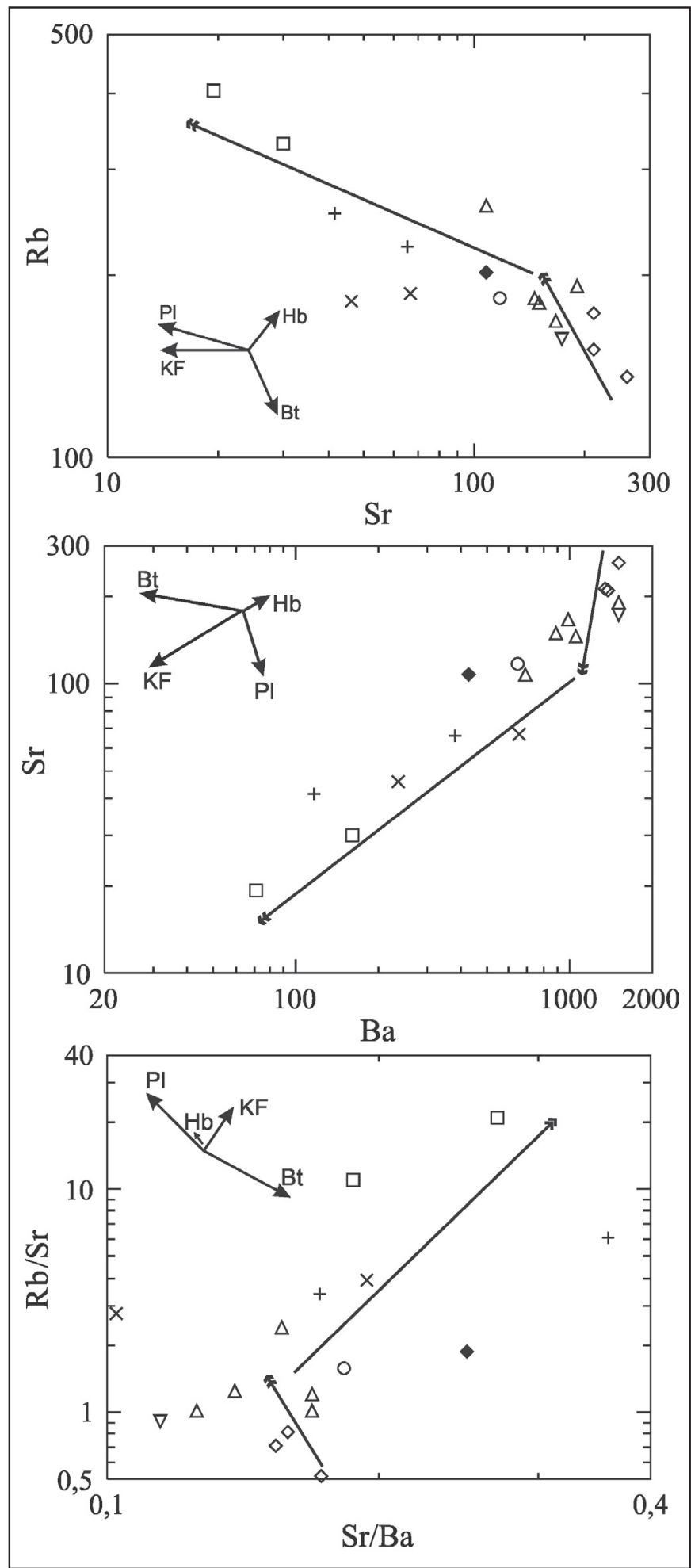

Figura 6 - Diagramas $R b$ x $\operatorname{Sr}(a)$, Sr $\times$ Ba (b) e Rb/Sr $\times \mathrm{Sr} / \mathrm{Ba}$ (c) para as diversas fácies petrográficas do Granito Bannach. Os vetores indicam a influência do fracionamento do plagioclásio (Pl), feldspato potássico (Fk), anfibólio (Anf) e biotita (Bt) na composição do líquido residual. As setas duplas indicam estágios de evolução magmática. Simbologia das fácies e suas abreviações conforme figura 3.

diferentes proporções a maior parte do Ba existente. $\mathrm{O}$ fracionamento de feldspato potássico acentuou-se nos ABMzG e BMzP, de tal modo que, quando da cristalização dos leucogranitos, o líquido magmático estava muito empobrecido neste elemento.
As variações de $\mathrm{Rb}$, $\mathrm{Sr}$ e $\mathrm{Ba}$ são geralmente usadas para estimar o grau de fracionamento e especular sobre os processos petrogenéticos que controlaram a evolução de um corpo (Hanson 1989, 1989, Dall'Agnol et al. 1999). Os diagramas $\mathrm{Rb}-\mathrm{Sr}$, Sr-Ba e Rb/Sr-Sr/Ba (Figura 6) sugerem dois estágios de evolução magmática: $\mathrm{O}$ primeiro estágio, dos $\mathrm{BAMzG}$ para os $\mathrm{ABMzG}$ e $\mathrm{BMzP}$, reflete a predominância do fracionamento do plagioclásio e anfibólio, com feldspato potássico subordinado. $\mathrm{O}$ segundo estágio corresponde ao trend $\mathrm{BMzP}-$ leucogranitos, sendo caracterizado também pelo fracionamento de plagioclásio, porém com participação dominante de feldspato potássico. $\mathrm{O}$ comportamento do $\mathrm{Rb}$ e Ba nos estágios 1 e 2 indica que os efeitos do fracionamento da biotita foram totalmente subordinados em relação ao dos feldspatos na maioria das fácies do Granito Bannach.

Comportamento do $\mathrm{Zr}$, Y e Nb No Granito Bannach, os valores de $\mathrm{Zr}$ decrescem com o aumento de $\mathrm{SiO}_{2}$, portanto no sentido de evolução de suas fácies, indicando que o fracionamento de zircão foi muito importante nos líquidos menos evoluídos (BAMzG e $\mathrm{ABMzG}$ ) e provocou a diminuição das suas concentrações nos líquidos mais evoluídos (BMzP e leucomonzogranitos). Há uma nítida correlação positiva entre valores de $\mathrm{Zr}$ e Ti, decrescendo das fácies menos evoluídas para os leucogranitos. Isso reflete a importância do fracionamento simultâneo de titanomagnetita, ilmenita e zircão na evolução das diferentes fácies.

O Y apresenta um comportamento irregular, predominando correlação negativa com $\mathrm{SiO}_{2}$, decrescendo no sentido BAMzGABMzG-LMzMp. Um comportamento distinto é mostrado pelo $\mathrm{Nb}$, que varia muito pouco no conjunto das rochas estudadas. Os $\mathrm{CBAMzG}$ possuem teores extremamente elevados de $\mathrm{Y}$ e $\mathrm{Nb}$, refletindo provavelmente a presença de fases cumuláticas ricas nesses elementos. Segundo Taylor (1965) o Y pode estar contido no anfibólio e nos minerais acessórios cálcicos. Como Y e Nb são compatíveis com hornblenda, titanita e zircão, eles poderiam estar presentes em grande parte nestes minerais, nas fácies mais ricas em ferromagnesianos. Esta explicação não é, porém, válida para alguns leucogranitos que apresentam valores de $\mathrm{Y}$ iguais ou superiores aos dos BAMzG e ABMzG. Nos primeiros, as fases minerais enriquecidas em $\mathrm{Y}$ não puderam ser identificadas. Os decréscimos regulares de $\mathrm{Y}$ e em parte do $\mathrm{Nb}$, no sentido BAMzG-ABMzG-LMzMp devem ter sido controlados pelo fracionamento dos ferromagnesianos mencionados.

Comportamento dos elementos terras raras Os dados analíticos dos elementos terras raras (ETR) foram normalizados pelos valores condríticos de Evensen et al. (1978).

A fácies $\mathrm{CBAMzG}$ é a que apresenta maior conteúdo de ETR (976 ppm), e menor grau de fracionamento dos ETR pesa$\operatorname{dos}\left[(\mathrm{La} / \mathrm{Yb})_{\mathrm{N}}=6,56\right]$ (Tabela 2). O seu alto conteúdo modal de anfibólio, titanita, apatita e, sobretudo, zircão pode explicar em parte a grande concentração em ETR. A pronunciada anomalia negativa de $\mathrm{Eu}\left(\mathrm{Eu} / \mathrm{Eu}^{*}=0,18\right)$ observada nesta rocha (Figura 7), pode ser conseqüência indireta da acumulação de fases máficas precoces tal como o anfibólio, possivelmente decorrente da atuação de processos de separação gravimétrica. Isso promoveu menor participação do plagioclásio na rocha, com diluição do conteúdo original de Eu.

A hipótese dos BAMzG serem produtos de cristalização fracionada a partir dos CBAMzG não é favorecida pela acentuada anomalia negativa de Eu que os últimos apresentam, uma vez que se existisse um líquido residual proveniente da cristalização dos $\mathrm{CBAMzG}$, ele não teria as características apresentadas pelos BAMzG. A comparação visual entre os padrões de CBA$\mathrm{MzG}$ e BAMzG (Figura 7) revela que os últimos derivaram de um líquido com fracionamento bem menos acentuado de pla- 


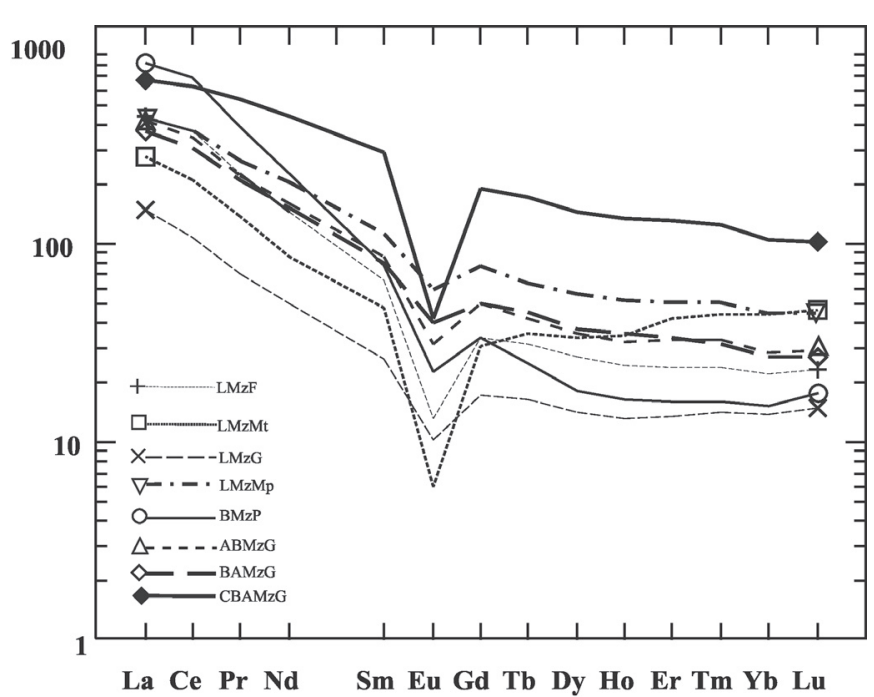

Figura 7 - Padrões de distribuição dos ETR de amostras representativas das diversas fácies do Granito Bannach. Simbologia das fácies e suas abreviações conforme figura 3

gioclásio. Essa evidência, juntamente com outras características dos CBAMzG, sugere que esta fácies teve uma evolução particular, provavelmente relacionada a processos cumuláticos.

Os teores totais de ETR nos BAMzG são menores (média de $373 \mathrm{ppm}$ ) do que nos $\mathrm{ABMzG}$ (415 ppm), porém estes últimos revelam um grau de fracionamento um pouco maior de ETRP, com razão $(\mathrm{La} / \mathrm{Yb})_{\mathrm{N}}$ média igual a 13,8 , enquanto que no BAMzG esta razão é de 11,4. Em ambos, a anomalia negativa de Eu é moderada, porém nota-se que esta anomalia é menos acentuada no BAMzG $\left(\mathrm{Eu} / \mathrm{Eu}^{*}=0,7\right)$, do que nos $\mathrm{ABMzG}(\mathrm{Eu} /$ $\left.\mathrm{Eu}^{*}=0,4\right)$.

A fácies BMzP é enriquecida em ETRL (758 ppm) e exibe anomalias de európio semelhantes à maioria das amostras de $\mathrm{ABMzG}\left(\mathrm{Eu} / \mathrm{Eu}^{*}=0,4\right)$. Na figura 7, nota-se um padrão côncavo para os ETRP desta rocha. Esse padrão côncavo dos ETRP foi também observado nas rochas do maciço Musa (Gastal 1987) e nos leucogranitos do Maciço Redenção (Oliveira 2001) e é interpretado como sendo indicador de fracionamento do anfibólio (Dall'Agnol et al. 1999).

Os conteúdos e o padrão de distribuição dos ETR dos LMzMp (Tabela 2; Figura 7) se aproximam muito daqueles dos $\mathrm{BAMzG}$ e $\mathrm{ABMzG}$, o que reforça a ligação genética entre ambos. O fato de a anomalia de Eu do LMzMp (0,65 - Tabela 2) ser muito próxima daquela dos $\mathrm{BAMzG}$ (média de 0,70 ) e ser menos acentuada do que nos $\mathrm{ABMzG}$ (média de 0,44 ) indica que os primeiros podem ter derivados diretamente dos $\mathrm{BAMzG}$ e não dos $\mathrm{ABMzG}$.

Os LMzG apresentam os menores conteúdos totais de ETR dentre as fácies (213 ppm) do Granito Bannach, com anomalia de európio $\left(\mathrm{Eu} / \mathrm{Eu}^{*}=0,53\right)$ muito similar aquelas da fácies $\mathrm{AB}$ MzG. Os baixos valores médios da razão $\left[(\mathrm{La} / \mathrm{Yb})_{\mathrm{N}}=11,3\right]$ indicam que não houve fracionamento muito expressivo de fases enriquecidas em ETRP, tais como anfibólio e zircão.

Os LMzMt também mostram um fracionamento pouco acentuado dos ETRP [média de $(\mathrm{La} / \mathrm{Yb})_{\mathrm{N}}=8,96$ ], além de uma marcante anomalia negativa de európio $\left(\mathrm{Eu} / \mathrm{Eu}^{*}=0,16\right)$, que indica importante fracionamento de plagioclásio e feldspato potássico. O conteúdo de ETR e o padrão de distribuição dos LMzF diferem daqueles dos LMzMt, sendo os primeiros mais enriquecidos em ETR (média de $470 \mathrm{ppm}$ ) e exibindo maior fracionamento de ETRP $\left[(\mathrm{La} / \mathrm{Yb})_{\mathrm{N}}=17,5\right]$ e menor anomalia negativa de $\mathrm{Eu}\left(\mathrm{Eu} / \mathrm{Eu}^{*}=0,31\right)$.
As diferenças nos conteúdos e na distribuição dos ETR nos leucogranitos sugerem evoluções ligeiramente distintas entre estas rochas. O padrão de distribuição dos ETR da fácies LMzMp difere um pouco dos demais leucogranitos, se assemelhando com o dos BAMzG e ABMzG. As anomalias de Eu menos acentuadas que os $\mathrm{LMzMp}$ e $\mathrm{LMzG}$ exibem em relação aos LMzMt e LMzF indicam que os mesmos foram originados a partir de líquidos um pouco menos evoluídos do que aqueles que formaram os LMzMt e LMzF. Um fracionamento mais limitado de plagioclásio nos líquidos que precederam o gerador dos LMzMp e LMzG, poderia explicar as moderadas anomalias de európio observadas nessas rochas, ao passo que os LMzMt e $\mathrm{LMzF}$ foram possivelmente derivados de líquidos extremamente evoluídos, precedidos em sua evolução por um fracionamento muito intenso de plagioclásio. Uma maior afinidade geoquímica entre os $\mathrm{LMzMp}, \mathrm{LMzG}$ e os $\mathrm{BAMzG}$ e $\mathrm{ABMzG}$ é sugerida pela presença nos LMzMp e LMzG de anfibólio, titanita e allanita, ausentes nos LMzMt e LMzF.

TIPOLOGIA E AMBIENTE TECTÔNICO A classificação de granitos tipos I e $S$ baseia-se na natureza das fontes de seus magmas, sendo uma classificação genética, para granitóides derivados de fontes ígneas e sedimentares, respectivamente. Ela foi introduzida em estudos do Lachlan Fold Belt na Austrália, sendo utilizados parâmetros mineralógicos e químicos para a separação destes dois tipos (Chappell \& White 1992 e referências naquele trabalho).

Loiselle \& Wones (1979) introduziram a terminologia de granito tipo-A, para designar granitos anorogênicos e de natureza alcalina e supostamente de caráter anidro. Geoquimicamente, apresentam valores elevados de $\mathrm{SiO}_{2}(>70 \%), \mathrm{Fe} / \mathrm{Mg}, \mathrm{Zr}, \mathrm{Nb}, \mathrm{Y}$, $\mathrm{Ga}$, e ETR, com exceção do $\mathrm{Eu}$, e baixos $\mathrm{CaO}, \mathrm{MgO}$, Ba e $\mathrm{Sr}$ (Whalen et al. 1987).

A gênese de granitos do tipo A foi inicialmente explicada a partir de duas hipóteses principais: cristalização fracionada de magmas basálticos alcalinos (Eby 1992) e fusão parcial de crosta granulítica residual (Collins et al. 1982).

As características gerais do Granito Bannach são, à primeira vista, tanto compatíveis com os granitos do tipo I, quanto com os granitos do tipo A. Dentre elas destacam-se a presença de anfibólio, biotita e magnetita, sua tendência subalcalina, o caráter metaluminoso a peraluminoso, com coríndon normativo $<1$ e o caráter oxidante. Por outro lado, seus altos teores de $\mathrm{SiO}_{2}(69-$ $77 \%$ ), $\mathrm{K}_{2} \mathrm{O}+\mathrm{Na}_{2} \mathrm{O}, \mathrm{Zr}, \mathrm{Nb}, \mathrm{Y}$ e Ga, suas altas razões $\mathrm{K}_{2} \mathrm{O} / \mathrm{Na}_{2} \mathrm{O}$ (entre 1 e 2) e $\mathrm{Ga} / \mathrm{Al}$ o aproximam mais do tipo A. Entretanto, seus teores de $\mathrm{TiO}_{2}, \mathrm{CaO}, \mathrm{MgO}, \mathrm{Sr}$ e Ba são relativamente altos, quando comparados com os granitos tipo A do cinturão australiano (Whalen et al. 1987, King et al. 1997).

Whalen et al (1987) recomendam o uso da razão $\mathrm{Ga} / \mathrm{Al}$ como discriminantes de granitos do tipo A. Nos diagramas $\mathrm{Zr}$ x $\mathrm{Ga} / \mathrm{Al}$ (Figura 8a) e $\left(\mathrm{K}_{2} \mathrm{O}+\mathrm{Na}_{2} \mathrm{O} / \mathrm{CaO} \times \mathrm{Zr}+\mathrm{Nb}+\mathrm{Ce}+\mathrm{Y}\right)$ (Figura $8 \mathrm{~b})$ verifica-se que o Granito Bannach apresenta afinidade com os granitos do tipo A. Além disso, no diagrama Nb-Y (Figura 8c) de Pearce et al. (1984), o Granito Bannach possuem afinidades geoquímicas com granitos intraplaca, o que é característico de granitos do tipo A (Whalen et al. 1987).

$\mathrm{O}$ diagrama $\mathrm{FeOt} /(\mathrm{FeOt}+\mathrm{MgO})$ versus $\mathrm{SiO}_{2}$ (Figura 8d), proposto por Frost et al. (2001) para classificar granitóides com base nas condições de oxidação, as amostras do Granito Bannach incidem no campo dos granitos ferrosos que coincide com aquele dos granitos do tipo A.

Segundo a classificação de Eby (1992), para discriminar granitóides de fonte mantélica $\left(A_{1}\right)$ e de fonte crustal $\left(A_{2}\right)$, o Granito Bannach possui afinidades geoquímicas com o subtipo $\mathrm{A}_{2}$, sugerindo fonte crustal para o mesmo. 
ENQUADRAMENTO DO CORPO BANNACH NA SUÍTE JAMON O Granito Bannach apresenta similaridades marcantes com os corpos Jamon (Dall'Agnol et al. 1999, 2005), Musa (Gastal 1987, Dall'Agnol et al. 1999, 2005) e Redenção (Oliveira 2001), todos pertencentes a Suíte Jamon. Esses granitos são isotrópicos, intraplacas, de alto nível crustal, tendo sido colocados em uma crosta rígida, cortando discordantemente suas rochas encaixantes. $\mathrm{O}$ zoneamento interno que ocorre no corpo Bannach também é observado nos maciços Redenção, Musa e Jamon (Oliveira et al. 2004).

O Granito Bannach também é muito similar em termos de composição modal aos granitos da Suíte Jamon (Figura 9a). Suas composições se sobrepõem em parte ou inteiramente àquelas observadas nos demais granitos. Assim como ocorre no Granito Bannach, as fácies monzograníticas dos maciços da suíte são texturalmente bastante variadas, apresentando desde termos com granulação grossa, equigranulares ou porfiríticos até heterogranulares médios a grossos ou médios a finos e equigranulares médios.

São metaluminosos a peraluminosos (Figura 9b) e possuem afinidades com os granitos do tipo-A, incidindo no campo dos granitos do subtipo A2. O diagrama $\mathrm{K}_{2} \mathrm{O}$ versus $\mathrm{Na}_{2} \mathrm{O}$ (Figura $9 \mathrm{c})$ mostra que as razões $\mathrm{K} 2 \mathrm{O} / \mathrm{Na}_{2} \mathrm{O}$ do Granito Bannach se superpõem àquelas dos demais granitos da Suíte Jamon e aumentam gradualmente com a diferenciação magmática com valores entre 1 e 2.

Outras características que aproximam o Granito Bannach daquelas pertencentes aos granitos da Suíte Jamon são os conteúdos expressivos de minerais opacos, os altos valores de suscetibilidade magnética e a presença marcante da paragênese magnetita-titanita-quartzo, as quais são coincidentes com àquelas apresentadas pelos granitos da série magnetita (Ishirara 1981), formados em condições de fugacidade de oxigênio $\left(\mathrm{fO}_{2}\right)$ próximas daquelas dos tampões NNO e HITMQ (Wones 1989).

O diagrama $\mathrm{FeOt} /(\mathrm{FeOt}+\mathrm{MgO})$ versus $\mathrm{SiO}_{2}$ (Figura 9d), mostra que a distribuíção das rochas do Granito Bannach coincide com àquelas dos granitos da Suíte Jamon. $\mathrm{O}$ corpo Bannach juntamente com os granitos Musa, Jamon e Redenção são do tipo ferroso (Frost et al. 2001) e revelam comportamento similar aos dos granitos tipo-A oxidados (Dall'Agnol et al. 2005). Também são
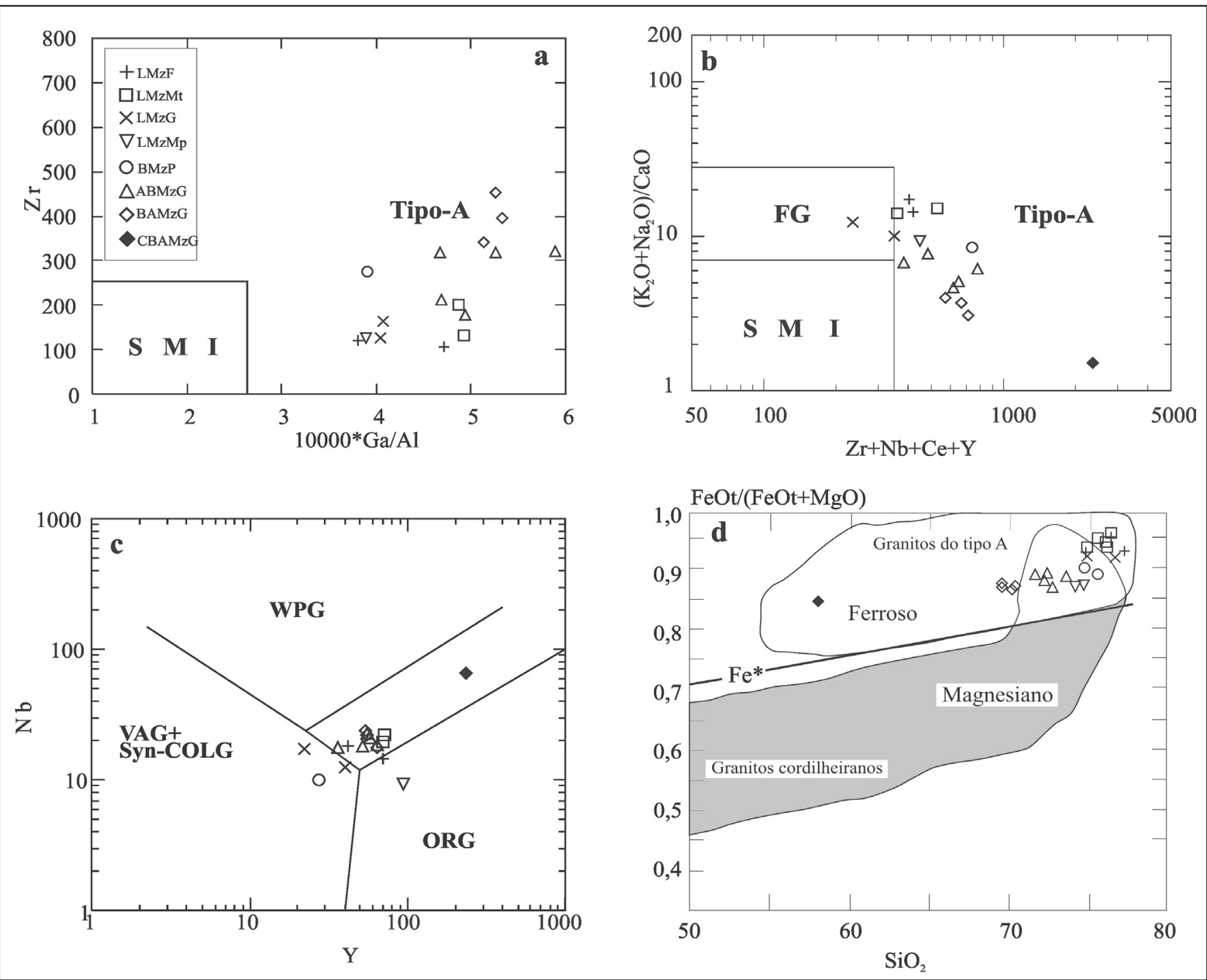

Figura 8-Diagramas de elementos traços das diversas fácies do Granito Bannach. (a) diagrama Zr x Ga/Al ( Whalen et al. 1987); (b) diagrama $\mathrm{K}_{2} \mathrm{O}+\mathrm{Na}_{2} \mathrm{O} / \mathrm{CaO} \times \mathrm{Zr}+\mathrm{Nb}+\mathrm{Ce}+\mathrm{Y}$ ( Whalen et al. 1987). M, I e S: médias dos granitos tipo M, I e S; FG: granitos félsicos fracionados; (c) diagrama NbxY (Pearce et al. 1984). Campos syn-COLG: Granitóides Sin-colisionais, VAG: Granitóides de Arcos Vulcânicos, ORG: Granitóides de Cadeias Oceânicas e WPG: Granitóides intra-placa; (d) diagrama FeOt/(FeOt + MgO) versus $\mathrm{SiO}_{2}$ (Frost et al. 2001). Abreviações conforme a figura 3. 
evidentes as analogias dos padrões de ETR entre as fácies afins dos granitos da Suíte Jamon e àquelas do Granito Bannach.

As comparações feitas em termos petrográficos, geoquímicos, juntamente com as relações de campo, permitem que o Granito Bannach seja enquadrado dentro da Suíte Jamon, uma vez que apresenta notáveis similaridades com os corpos que compõem a mesma (Jamon, Musa e Redenção).

CONCLUSÕES A integração dos dados geológicos, petrográficos e geoquímicos revelou a existência de oito fácies petrográficas, divididas em três grandes conjuntos composicionais: a) Rochas portadoras de anfibólio + biotita \pm clinopiroxênio (CBAMzG, BAMzG e $\mathrm{ABMzG}$ ); b) fácies portadora de biotita com textura porfirítica $(\mathrm{BMzP})$; $\mathrm{c})$ fácies leucograníticas (LMzG, LMzMp, LMzMt e LMzF). A distribuição espacial destas fácies mostra que o maciço é zonado composicionalmente com as fácies mais ricas em máficos situando-se nas bordas do corpo e as mais leucocráticas nas porções centrais.

As composições modais e químicas das diversas fácies do Granito Bannach indicam a existência de passagens graduais entre os grupos de fácies permitindo supor trends de evolução por processos de diferenciação magmática no sentido BAMzGABMzG-BMzP-LMzMp-LMzG-LMzF. Tal diferenciação se traduziu pela diminuição dos teores dos ferromagnesianos e das razões plagioclásio/microclinio e anfibólio/biotita, e por aumentos moderados nas quantidades de quartzo. Muito provavelmente, essas variações foram também acompanhadas pelo decréscimo do teor de anortita do plagioclásio. As características petrográficas e geoquímicas dos $\mathrm{CBAMzG}$ sugerem que sua gênese está ligada provavelmente a processos cumuláticos. Já os LMzMt são interpretados como intrusões separadas formadas a partir de líquidos bastante evoluídos e independentes daquele formador das demais fácies.

Através da relação dos elementos litófilos ( $\mathrm{Rb}, \mathrm{Sr}$ e $\mathrm{Ba})$ e ETR foi possível distinguir dois estágios de evolução magmática. O primeiro estágio, dos $\mathrm{BAMzG}$ para os $\mathrm{ABMzG}$ e $\mathrm{BMzP}$, reflete a predominância do fracionamento do plagioclásio e anfibólio, com feldspato potássico subordinado. O segundo estágio corresponde ao trend BMzP-leucogranitos, sendo caracterizado também pelo fracionamento de plagioclásio, porém com participação dominante de feldspato potássico. $\mathrm{O}$ aumento da anomalia de európio no sentido BAMzG-leucogranitos revela que o fracionamento de plagioclásio foi muito importante ao longo da evolução das diferentes fácies. $\mathrm{O}$ comportamento do $\mathrm{Rb}$ e Ba nos dois estágios indica que os efeitos do fracionamento da biotita foram totalmente subordinados em relação aos dos feldspatos na maioria das fácies do Granito Bannach.

O Granito Bannach mostra afinidades geoquímicas com gra-
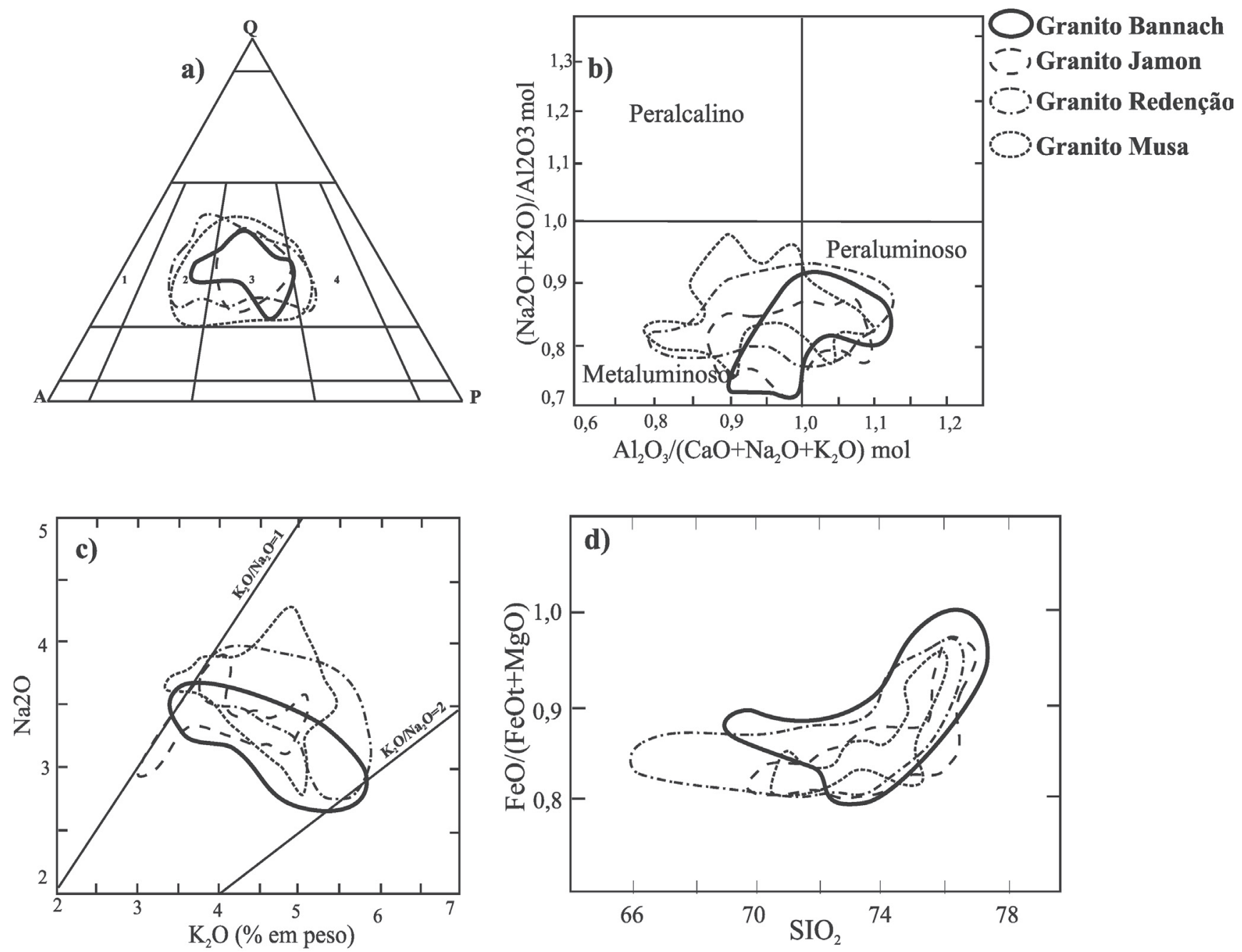

Figura 9 - Diagramas comparativos entre o Granito Bannach e os granitos Jamon, Musa e Redenção pertencentes a Suite Jamon; a) Q-A-P (Le Maitre 2002). Campos: 1- Álcali-feldspato Granito, 2 - Sienogranito, 3 - Monzogranito, 4 - Granodiorito; b) A/NK versus A/CNK (óxidos em proporções moleculares); c) $\mathrm{Na}_{2} \mathrm{O}$ versus $\mathrm{K}_{2} \mathrm{O}$ (\% em peso); d) $\mathrm{FeOt} /\left(\mathrm{FeOt}+\mathrm{MgO}\right.$ ) versus $\mathrm{SiO}_{2}(\%$ em peso). 
nitos tipo-A e nítidas semelhanças com os granitos que compõem a Suíte Jamon (Jamon, Musa e Redenção), justificando inteiramente o enquadramento do primeiro na referida suíte.

Agradecimentos Agradecemos aos pesquisadores do Grupo de Pesquisa Petrologia de Granitóides (GPPG-CG-UFPA) pelo apoio nas diversas etapas deste trabalho; à CAPES pela concessão da bolsa de mestrado ao primeiro autor; ao Centro de Geociências (CG-UFPA) pelo suporte técnico; ao CNPq pelo apoio ao desenvolvimento da pesquisa (55.0739/01-7, 476075/03-3). Este artigo é uma contribuição para o projeto PRONEX/CNPq (Proj. 103/98 - Proc. 66.2103/1998-0)

\section{Referências}

Althoff F.J., Barbey P., Boullier A.M. 2000. 2.8-3.0 Ga plutonism and deformation in the SE Amazonian craton: the Archean granitoids of Marajoara (Carajás Mineral province, Brazil). Precambrian Research., 104:187-206.

Anderson J.L. \& Morrison J. 2005. Ilmenite, magnetite, and peraluminous Mesoproterozoic anorogenic granites of Laurentia and Baltica. Lithos., 80:45-60.

Chappell B.W. \& White A.J.R. 1992. I-and S-type granites inthe LachlanFold Belt. Trans. Royal Soc. Edinburgh: Earth Sci., 83:1-26.

Collins W. J., Beams S. D., White A.J.R., Chappell B.W. 1982. Nature and Origin of A-type granites with particular reference to Southeastern Austr alia. Contrib. Mineral. Petrol., 80:189-200.

CPRM 2000. Programa de levantamentos geológicos básico do Brasil, Folha Xinguara (SB-22-Z-C), Estado do Pará. 120p (relatório técnico).

Dall'Agnol R., Lafon J.M., Macambira M.J.B. 1994. Proterozoic anorogenic magmatism in the Central Amazonian Province, Amazonian Craton. Geochronological, petrological and geochemical aspects. Miner. and Petrol., 50:113-138.

Dall’Agnol R., Ramö O.T., Magalhães M.S., Macambira M.J.B. 1999. Petrology of the Anorogenic, Oxidised Jamon and Musa Granites, Amazonian Craton: Implications for the genesis of Proterozoic, Atype Granites. Lithos., 46:431-462.

Dall'Agnol R., Souza Z.S., Althoff F.J., Barros C.E.M., Leite A. A. S., Jorge João X.S. 1997. General aspects of the granitogenesis of the Carajás metallogenic province. In: Intern. Symp. on Gran. and Associated Mineralizations, 2. Superitendência de Geologia e Recursos Minerais-SGM, Salvador, Atas, pp.135-161.

Dall'Agnol R., Teixeira N.P., Rämö O.T., Moura C.A.V., Macambira M.J.B., Oliveira D.C.O. 2005. Petrogenesis of the paleoproterozoic rapakivi A-type granite of the Archean Carajás Metallogenetic Province, Brazil. Lithos. 80:101-129.

Debon F., Le Fort P., Sabaté P. 1988. Uma classificação químico-mineralógica das rochas plutônicas comuns e suas associações, método e aplicações. Revista Brasileira de Geociências, 18(2):122-133.

DOCEGEO (Rio Doce Geologia e Mineração - Distrito Amazônia) 1988. Revisão litoestratigráfica da província mineral de Carajás, Pará. In: SBG, Congresso Brasileiro de Geologia, 35, Belém, Volume Província Mineral de Carajás-Litoestratigrafia e Principais Depósitos Minerais, Anexos, p.11-54.

Eby G. N. 1992. Chemical subdivision of the A-type granitoids: Petrogenetic and tectonic implications. Geology, 20:641-644.

Evensen N.M., Hamilton P.J., O'nions, R.K. 1978. Rare Earth abundance in Chondritic meteorites. Geoch. Cosm. Acta, 42:1199-1212.

Frost B.R., Barnes C.G., Collins W.J., Arculus R.J, Ellis D.J, Frost C.D. 2001. A geochemical classification for granitic rocks. Journal of Petrology 40:261-293.

Gastal M.C.P. 1987. Petrologia do Maciço Granítico Musa, sudeste do Pará. Dissertação de Mestrado, Centro de Geociências, Universidade Federal do Pará, Pará, 316 p.

Hanson G.N. 1989. An Approach to Trace Element Modeling Using a Simple Igneous System as an Example. In: B.R. LIPIN \& G.A. McKAY (Eds.), Geochemistry and Mineralogy of Rare Earth Elements. Mineralogical Society of America, Washington, D.C., pp.: 79-97. (Reviews in Mineralogy, 21).

Hibbard M.J. 1995. Mixed Magma Rocks. Petrography To Petrogenesis. Prentice-Hall, Inc. P., New Jersey, p. 242-260.

Huhn S.R.B., Santos A.B.S., Amaral, A.F., Ledsham E.J., Gouveia, J.L., Martins L.B.P., Montalvão R.M.G., Costa V.G. 1988. O terreno granito-greenstone da região de Rio Maria - Sul do Pará. In:
SBG, Cong. Bras. Geol., 35, Belém, Anais. v. 3, p. 1438-1453.

Ishihara S. 1981. The granitoid series and mineralization. In: B.J. Skinner (ed.) Economic Geology, 75th anniversary volume, p. 458484.

King P. L., White A.J.R., Chappell B.W., Allen C.M. 1997. Characterization and origin of aluminous A-type granites from the Lachlan Fold Belt, southeastern Australia. Journal of Petrology, 38:371391.

Le Maitre R.W. 2002. A classification of igneous rocks and glossary of terms. 2nd Edition, London, 193 p.

Leite A.A.S. 2001. Geoquímica, petrogênese e evolução estrutural dos Granitóides Arqueanos da Região de Xinguara, SE do Cráton Amazônico. Tese de Doutorado, Centro de Geociências, Universidade Federal do Pará, 330p.

Loiselle M.C. \& Wones D.R. 1979. Characteristics and origin of anorogenic granites. Geol. Soc. Am. Abstr. Prog., 11:468.

Montalvão R.M.G., Bezerra P.E. L., Prado P., Fernandes C.A.C., Silva G.H., Brim R.P. 1982. Características petrográficas e geoquímicas do Granito Redenção e suas possibilidades metalogenéticas. In: SBG, Congr. Bras. Geol., 32, Salvador, Anais, vol. 2, p.520-548.

Oliveira D. C. 2001. Geologia, geoquímica e petrologia magnética do Granito Paleoproterozóico Redenção, SE do Cráton Amazônico. Dissertação de Mestrado, Centro de Geociências, Universidade Federal do Pará, 207 p.

Oliveira D.C., Dall'Agnol R., Almeida. J.A.C. 2004. Zoneamento dos Corpos paleoproterozócos da Suíte Jamon, SE do Cráton Amazônico. In: SBG, Cong. Bras. Geol., 42, Araxá, Anais, CD-ROM.

Pearce J.A., Harris N.B.W., Tindle A.G. 1984. Trace Element Discrimination Diagrams for the tectonic interpretation of granitic rocks. Jour. Petro., 25:956-983.

Souza Z.S. 1994. Geologia e petrogênese do "Greenstone Belt" Identidade: implicações sobre a evolução geodinâmica do terreno granito- "greenstone" de Rio Maria, SE do Pará. Tese de Doutorado, Centro de Geociências, Universidade Federal do Pará, 624p.

Taylor S.R., 1965. The application of trace element data to problems in petrology. In: L.H. Ahrens, K.Rankama, S.K. Runcon (Eds.) Physics and Chemistry of the Earth. Pergamon Press, London, v. 6, p.133-213.

Tassinari C.C.G. \& Macambira M.J.B. 1999. Geochronological Provinces of the Amazonian Craton. Episodes, 22:174-182.

Vale A.G. \& Neves P.N. 1994. O Granito Redenção: Estado do Pará. In: SBG, Congr. Bras. Geol., 38, Balneário Camboriú-SC, Anais, vol. 1, p. 149-150.

Wedepohl K.H. 1970. Rubidium, Handbook Of Geochemistry. Springer-Verlag, Berlin, p. 37-B - 37-N.

Wedepohl K.H. 1972. Barium, Handbook Of Geochemistry. SpringerVerlag, Berlin, p. 56-D - 56-N.

Wedepohl K.H. 1974. Strontium, Handbook Of Geochemistry. Berlin, Springer-Verlag, p. 38-A - 38-N.

Wernick E. 2004. Rochas magmáticas: conceitos fundamentais e classificação modal, química, termodinâmica e tectônica. Unesp, São Paulo, 655p.

Whalen J.W., Currie K.L., Chappel B.W. 1987. A-type granites: geochemical characteristics, discrimination and petrogenesis. Contrib. Mineral. Petrol. 95:407-419.

Wones D.R. 1989. Significance of the assemblage titanite + magnetita + quartz in granitic rocks. American Mineralogist, 74:744-749.

Manuscrito A-1594 Revisão aceita em 3 de agosto de 2006 